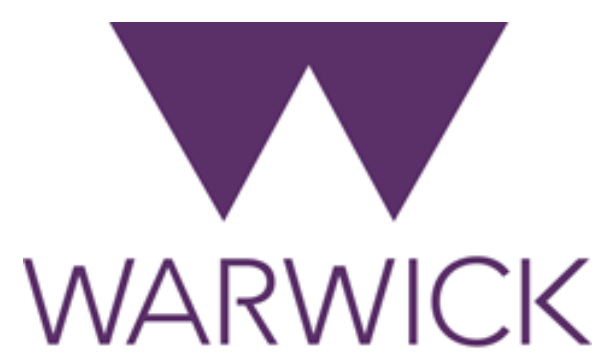

THE UNIVERSITY OF WARWICK

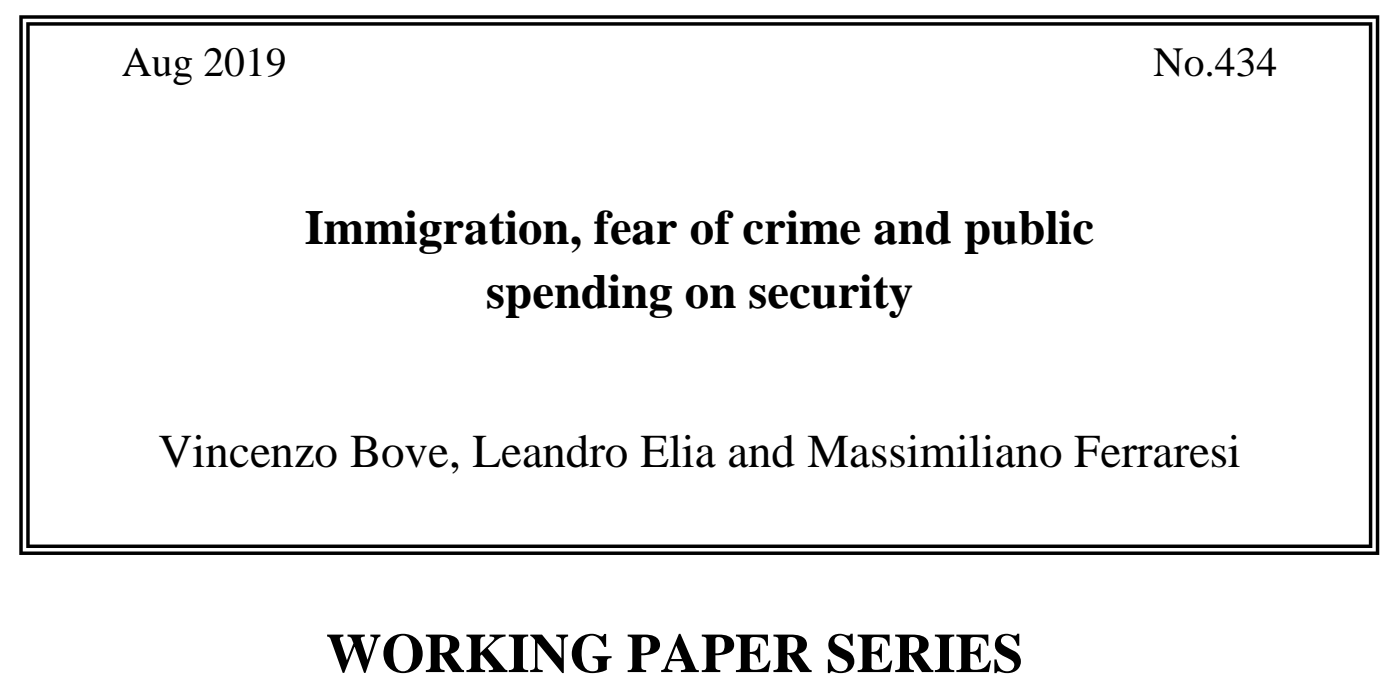

Centre for Competitive Advantage in the Global Economy

Department of Economics 


\title{
Immigration, fear of crime and public spending on security $\|^{2}$
}

\author{
Vincenzo Bovep Leandro Eliaf $\quad$ Massimiliano Ferraresi]
}

\begin{abstract}
We explore the relation between immigration, crime and local government spending on security in Italian municipalities. We find that immigration increases the share of public resources devoted to police protection, particularly when migrants are culturally distant from the native population. We uncover a misalignment between perception and reality, as immigration increases fear of future crimes rather than the actual probability of being victim of a crime. We also demonstrate that immigration from culturally distant societies is associated with a deterioration in civic cooperation and interpersonal trust, which can affect perceptions of safety and the demand for police services.
\end{abstract}

JEL classification: H71; J15; D72; F52

${ }^{a}$ We thank seminar participants at the Catholic University of the Sacred Heart, Milan, the Marche Polytechnic University, the University of Pisa, the University of Warwick and the University of Ferrara for helpful comments and discussions. The scientific output expressed does not imply a policy position of the European Commission. Neither the European Commission nor any person acting on behalf of the Commission is responsible for the use which might be made of this publication.

${ }^{\mathrm{b}}$ Department of Politics and International Studies and CAGE (Competitive Advantage in the Global Economy), University of Warwick, Coventry CV4 7AL; e-mail: v.bove@warwick.ac.uk

${ }^{\mathrm{c}}$ Department of Economics and Social Sciences, Marche Polytechnic University; e-mail: l.elia@univpm.it

${ }^{\mathrm{d}}$ European Commission, Joint Research Centre (JRC), Ispra, Italy; e-mail: massimiliano.ferraresi@ec.europa.eu 


\section{Introduction}

Since 2000, the size of transnational migration has continued to grow rapidly worldwide, with the number of persons living in a country other than where they were born increasing by $50 \%$ between 2000 and 2017 (UN DESA, 2017). Immigration offers valuable economic opportunities and gains for both migrants and their host societies, and there is by now a considerable body of work on the effects of immigration on economic growth, unemployment and wages (see e.g., Friedberg and Hunt, 1995; Card et al., 2012; Dustmann et al., 2012; Boeri et al., 2015). Yet, the arrival of new immigrants often stoke social and political tensions and cause security concerns. In this article, we explore whether and to what extent immigration leads to a largely neglected but important outcome, government spending on public security.

The consequences of immigration today are not only a salient issue but also a contentious one in most of the destination countries, splitting public opinion and fueling negative attitudes towards immigrants. There are at least three main concerns that drive hostility against immigration. The first is the consequence of immigration for the wage of low-skilled workers, despite existing evidence of either a modest or even a positive effect on the salaries of less educated native-born workers (e.g., Peri and Sparber, 2009; Ottaviano and Peri, 2012). The second concern revolves around the perceived fiscal burden placed by immigrants on public finances as recipients of generous social transfers, "as much as and probably more than by effects on labour market outcomes" (Preston, 2014, p.569. See also Boeri, 2010). The third concern, which is the focus of our article, is the perceived effect of immigration on crime. As immigrants often share the same socio-economic risk factors that are typically associated with high-crime populations, few issues have gained more media coverage than the perceived impact of immigration on crime. Existing research convincingly shows that immigrants are not more crime prone than their native-born counterparts, that they do not significantly increase the overall crime rate or the number of violent crimes and that legalization further reduces the crime rate of immigrants (see e.g., Bianchi et al., 2012; Bell et al., 2013; Mastrobuoni and Pinotti, 2015; Pinotti, 2017; Light and Miller, 2018). Yet, there is plenty of anecdotal evidence suggesting that immigration is often associated with an increase in the fear of crime. A collective perception of insecurity can lead to the implementation of unnecessarily restrictive regulations and control mechanisms, including surveillance and profiling programs. It can also lead to unhelpful and potentially wasteful additional public spending on security.

In this article we explore how immigration shapes public spending on police protection in Italian municipalities. Indeed, Italy illustrates this point clearly. The debate about law and order has intensified in the country since more than 600,000 would-be migrants have arrived across the Mediterranean on to Italian shores between 2014 and 2017. Since 2007, crime rates per 1,000 inhabitants have decreased by almost $25 \%$ across all Italian regions. Crimes perpetrated by foreign residents show a similar decreasing trend. Yet, by one estimate, $60 \%$ of Italians do not feel safe in their cities 1 Matteo Salvini, the deputy prime minister as well as the minister of interior and leader of the League, has

\footnotetext{
${ }^{1}$ See http://www.swg.it/politicapp?id=ijkr. Moreover, the 2018 report of the research institute Censis finds a "widespread bitterness" among Italians, with $63 \%$ of respondents reporting a negative opinion about immigration from non-EU countries, and $75 \%$ believing that immigrants lead to an increase in crime (Sole 24 Ore, 7/10/18).
} 
often blamed immigration for a lack of security and has pledged to recruit 10,000 new police officers (Il Giornale, 08/10/2018). This is not unique to the Italian case and similar patterns have been observed in other countries, such as Germany.2

Concerns about immigration often lead to tensions between locals and immigrants, religious prejudices or racist attitudes, the emergence of extremist groups and support for violence against outsiders (see e.g., Hainmueller and Hopkins, 2014, Barone et al., 2016; Halla et al., 2017). These tensions are often exploited by political parties to reap electoral gains. Not surprisingly, recent studies have uncovered a strong effect of immigration on the success of anti-immigrant parties (e.g., Barone et al., 2016; Halla et al., 2017; Brunner and Kuhn, 2018). At the same time, past work on immigration, and the size and composition of public spending, has emphasized changes in preferences for tax rates, public goods provision and redistribution as a consequence of increased ethnic heterogeneity (e.g., Alesina et al., 1999; Luttmer, 2001; Razin et al., 2002; Speciale, 2012; Dahlberg et al., 2012). However, in the case of local public finances, however, much less systematic evidence has been uncovered regarding immigration and the choice of specific public spending items (Gerdes, 2011). And no study has looked directly and systematically at one crucial aspect of the political effect of immigration, its impact on the share of public resources that local governments devote to security. Against this background, we provide new and, compared to what has been previously established by anecdotal examples, convincing empirical evidence of how immigration leads to more funding for public security in receiving municipalities. We also explore some of the underlying transmission mechanisms.

We use an exhaustive dataset with detailed information on local government spending for more than 7,000 Italian municipalities between 2003 and 2015, and combine it with municipal-level data on the population of foreign-born residents, including their country of origin. We leverage exogenous variations in immigration flows following recent rounds of enlargement of the European Union. We use the sudden increase of immigrants from new European Member States to construct a novel shift-share instrument. Interestingly, as Mastrobuoni and Pinotti (2015) put it, subsequent rounds of the EU enlargement attract new immigrants, whose characteristics may be quite different from those of previous migration waves. We complement this approach with historical data on migration and political preferences in the 1930s, during the Fascist regime. We find that immigration increases spending on police protection, such as enhanced police presence and surveillance. On average, the amount of spending allocated to local security increases by $0.12-0.30$ percentage points for one point increase in the share of immigrants. This is a very large effect, as municipalities spend on average about $4.3 \%$ of their budget on security, and they are often in serious financial distress. Moving beyond the dichotomy of immigrants-natives, we also incorporate the genetic, linguistic or religious proximity of foreign-born individuals to native populations into the relationship between migration flows and security spending. We find that the higher the distance the stronger the impact of immigration on law enforcement spending. Our results survive a variety of additional

\footnotetext{
${ }^{2}$ According to official figures, crime rate in the country in 2017 was at its lowest in 30 years, with fewer than 7,000 crimes committed per 100,000 inhabitants. Similarly, the proportion of non-German crime suspects continues to decline every year. Yet, by one estimate, 44 per cent of Germans feel less safe in public spaces than a few years ago (FT, 26/11/18). To address these concerns, the government has introduced new security measures, including plans to employ 15,000 more police officers.
} 
robustness checks.

We offer important insights into the mechanisms behind these results. It is possible that municipalities with larger immigrant concentrations may be associated with higher crime rates, which motivates higher spending on municipal police. We detect no effect of an increase in immigration on crime rates, so the impact we observe on security spending is hard to square with a migration-crime nexus. Alternatively, there could be a significant misalignment between perceptions of crime and reality at the local level, and immigration could increase people's fear of future crimes, as opposed to the actual probability of being a victim of crime. We use survey data to show that individuals whose neighbors are of different race, or birthplace, are more likely to report that fighting crime is a national priority, and to believe that immigrants increase crime problems. To dig deeper into these results, we ask why immigration shapes worry about crime and perceptions of feeling unsafe. Higher demand for public order and safety at the local level could be driven by a deterioration in the level of social capital, the ties and relationships that bind members of a society. Social capital is often used as an indicator of the cohesiveness of societies and the degree of peaceful coexistence and interactions among individuals. When social capital is eroded, we should observe more concerns about lack of security and increased demands for law and order (Liska and Warner, 1991; Buonanno et al., 2009). We find a negative impact of immigration on the number of nonprofit organizations, a common measure of the strength of social networks at the local level. Immigrants' country of origin seems to be again crucial and the coefficient is larger the higher the cultural distance between immigrants' home and host countries. Having neighbors of different race or foreign neighbors is similarly negatively related to trust in social interactions and erodes social cohesion and civic cooperation. At this point, we note that the erosion of social capital and the fear of crime provide a credible explanation for the observed pattern. En route, we offer additional results for more detailed policy prescriptions. First, to finance more police protection, local governments divert their resources away from cultural activities and business support services for the local community. Second, we find that immigrants increase the share of voting going to parties of the right, which usually support increased funding to law enforcement. In the following sections, we take stock of the existing literature on the economic implications of migration inflows. In particular, on the basis of current research, we ask whether and how immigration affects the choice of different public spending items; and why cultural dissimilarities should affect municipal spending on police protection.

\section{Immigration, cultural distance and public spend- ing}

Our research question lies at the intersection of two separate yet intertwined strands of research: one on ethnic diversity and public goods provision, and one on cultural distance and economic outcomes. In recent years, scholars have documented the importance of immigration and diversity in explaining public spending decisions A core contribution to the debate, Alesina et al. (1999), finds that in ethnically heterogeneous jurisdictions in the United States, the relative amount of spending that goes to core public goods like education and roads is low. There are two reasons behind this finding: first, heterogeneous 
communities value public goods less, as each group's utility for a specific public good diminishes if this is shared with other groups; second, different ethnic groups have diverging preferences over which type of public goods should be provided with tax revenues. In a similar vein, Alesina and Glaeser (2004) show that heterogeneous countries, such as some Latin American ones, have lower levels of social spending, whereas homogeneous communities, such as Scandinavian states, have a more generous welfare state.

The recent debate has increasingly focused on the welfare state, to assess whether immigrants are indeed a fiscal drain. In fact, a number of studies explore whether welfarestate generosity is a social magnet to immigrants, yet the results are mixed (see e.g., Borjas, 1999b; Levine and Zimmerman, 1999; Pedersen et al., 2008; Razin and Wahba, 2011). In the case of local public finances, limited systematic evidence has been uncovered regarding immigration and the choice of different public spending items. Using data on Danish municipalities from 1995 through 2001, Gerdes (2011) finds no evidence of a decline in the Danish welfare state (daycare, schools, healthcare, and care for the elderly) due to an increase in the share of immigrants.

To fully understand the impact of immigration on public spending, one needs to factor in the cultural distance between home and host societies. Economists have long argued that culture affects important economic outcomes, in particular patterns of international trade and economic development. For example, Spolaore and Wacziarg (2009) investigate what impedes the diffusion of technological and institutional innovations across societies. They find that important differences in societal norms, customs, and habits, proxied by genetic distance, act as barriers to the diffusion of development from the frontier country. Similarly, language barriers represent a major hurdle to trade between countries through its effect on transaction costs (see e.g., Melitz and Toubal, 2014). Particularly in the post-Cold War period the leading source of conflict seems to be cultural, and therefore cultural differences cause clashes over several issues including trade (see Gokmen, 2017, who empirically validates Huntington's (1993) Clash of Civilizations hypothesis). This literature has also pinpointed some of the channels through which immigration, and cultural differences, affect public spending. As Guiso et al. (2006, p.29) eloquently put it, "the opening through which culture entered the economic discourse was the concept of trust" 3 The contemporary literature on culture and economic outcomes has been jump-started by Arrow (1972) and Fukuyama (1995) who suggest that the level of trust in a society influences its economic success. Guiso et al. (2009) demonstrate how the perception of trust, taken from Eurobarometer surveys, increases trade across a sample of European countries. Interestingly, when they instrument trust using its long-term cultural building blocks, such as the commonality in religion and somatic/genetic distance, their estimates show larger coefficient. This finding implies that additional channels, besides trust, are likely to explain the impact of culture on economic outcomes.

The cultural distance between groups in a country is likely to make it harder to produce public goods, yet this argument has been subject to a rather limited number of cross-national empirical studies. Desmet et al. (2009) show that countries with high linguistic distance between groups have low levels of redistribution by the government.

\footnotetext{
3 Guiso et al. (2006) summarize why trust can affect economic decisions: "Trust is particularly relevant when transactions involve some unknown counterpart like a buyer or seller of goods in another country, when the transaction takes place over a period of time rather than being completed on the spot, and when the legal protection is imperfect." (Guiso et al., 2006, p.34).
} 
Belmonte et al. (2017) find that negative attitudes toward ethnic diversity reduce tax morale in centralized political systems, and this effect is lower in ethnically fragmented communities. These findings are based on the premise that individuals who are averted to ethnic diversity are more reluctant to contribute to the provision of public goods which can benefit other ethnic groups. While this brief overview cannot do justice to the broad knowledge generated by existing work, there is still limited evidence about the effect of immigration on local security spending and the underlying transmission mechanisms. In the remainder of the paper, we will explore whether and how immigration have a substantive, economically relevant, impact on local government spending on security. We find that immigration does affect the amount of resources devoted to police protection. Building on the literature surveyed in this section, we also show that the effect is stronger the higher the cultural distance of the immigrants from the native population. We then focus on more fine-grained stepping-stones to elucidate our main finding.

\section{Data}

The empirical analysis is based on a rich dataset of Italian municipalities. Italy is divided into 20 regions - five of which ruled by special statutes - 96 provinces, and as of 2019, 7,914 municipalities (comuni), the basic administrative division. All three levels have elected councils, own competences and financial resources. The density of Italian municipalities varies significantly by province and region: while, on average, an Italian municipality has about 6,400 inhabitants, $90 \%$ of them have less than 15,000 inhabitants. Thus even a small number of immigrants can have a meaningful effect on local spending decisions. We combine data from different archives to include municipal financial data, demographic and socio-economic characteristics, the country of origin of the permanent residents in each municipality, the cultural distances between immigrants and natives and data on different markers of social capital. Due to lack of information for some local governments, our final sample consists of a balanced panel of 7,234 municipalities, with 94,159 observations, from 2003 to 2015. Section A.1 of the Online Appendix provides detailed information on the institutional context and a more comprehensive background material on municipal spending and immigration in Italian municipalities.

Municipal financial data are released by the Ministry of Interior. All financial variables are computed in real terms using the consumption price index with base 2015 provided by the Italian National Statistical Office (ISTAT). Our core variable of interest is security spending, which includes police costs such as salaries, police presence and patrols, and the capital component in the production function for law enforcement, such as vehicles, communication devices and special clothing. We focus on security spending, computed as share of total current expenditure. Although data on disaggregated security spending are unavailable, Figure 1 shows that there is a very strong correlation between security spending and the number of local police officers in each municipality, thus suggesting that higher spending on security is likely to lead to changes in the size of the police force and a larger police presence.

$$
\text { [Figure } 1 \text { in here] }
$$

We control for an array of time-varying variables, taken from ISTAT. In particular, our models include the population size (population) and density (population density). We 
also compute the share of population aged 65 and older (share of $65+$ ) to capture social support requirements resulting from changes in population age structure. In terms of economic and financial data, we include the per capita personal income tax base (income) to capture average income. Furthermore, we account for the fiscal rules imposed by the central government on municipalities by setting a dummy variable (domestic stability pact) equals to 1 if a municipality has to comply with these rules (i.e., when they have a population of over 5,000) and zero otherwise. $4^{4}$

We also exploit information on resident population by municipality for the period 200315, taken from ISTAT. Each municipality keeps a population register (anagrafe), which records changes of residence from and to other Italian municipalities as well as other countries. Population register data are reported on a yearly basis (see Bonifazi et al. 2009). Interestingly, the decomposition of the standard deviation of migration shares into between and within variation shows that there are major variations in the number of migrants across municipalities as well as over time within each municipality ${ }^{5}$ At the same time, Italian municipalities show remarkable differences in the share of public spending on security, with a minimum of zero and a maximum of almost $47 \%$ and quite large variations over time (between $-14 \%$ to $40 \%$ ). To strengthen our identification strategy, we also take historical data on migration stock by province in 1936 and the share of votes for the National Fascist Party in 1929 Italian general election. These information are accessible from ISTAT historical archive which contains analyses, research and main documents produced by the institute in printed and electronic format.

Immigrants stem from a variety of countries of origin, and to comprehensively capture the degree of cultural affinity with the natives we use genetic, religious and linguistic distances. Genetic distance captures differences in allele frequencies across a range of neutral genes and Spolaore and Wacziarg (2016) show that genetic distance capture a wide array of cultural traits transmitted intergenerationally within populations over the long run ${ }^{6}$ By measuring the time since two populations shared common ancestors, genetic distance provides an ideal summary of differences in slowly changing genealogically transmitted characteristics, including habits and customs (Spolaore and Wacziarg, 2009, p. 523). We add a measure of religious distance based on the World Christian Database (WCD) on the prevalence of religion in each country and taken from Spolaore and Wacziarg (2016). In terms of linguistic proximity, to establish a close link with recent works, we use two indexes, one based on language trees (Fearon, 2003) and another one based on lexicostatistics (Dyen et al., 1992). In the former languages are grouped into families based on similarities between them and it is therefore based on a discrete number of common

\footnotetext{
${ }^{4}$ The domestic stability pact is an agreement with the central government on balance targets designed to meet government budget targets under the European Stability and Growth Pact.

${ }^{5}$ On the one hand, there are some municipalities, such as Rocca de Giorgi, Airole and Baranzate, which are strongly characterized by the presence of migrants, and where the share of foreign residents over the total population is close to $30 \%$. On the other hand, municipalities, such as Loreglia, Parlasco, Rondanina, Siapiccia, Sagama, Escolca and Montebello sul Sangro, did not record any new immigrant in the period 2003-2015.

${ }^{6}$ There are several versions of this variable (see Cavalli-Sforza et al., 1994) and the one we use, from Spolaore and Wacziarg $(2009)$ and called $F_{S T}$, is a measure of distance to the most recent common ancestors of two populations, i.e. their degree of genealogical relatedness, or equivalently, the length of time since two populations split apart. $F_{S T}$ is constructed using information on 128 alleles related to 45 selectively neutral genes. It includes alleles coding for blood groups, immunoglobulin, hemoglobin, enzymes and lymphocyte antigens (Spolaore and Wacziarg, 2009).
} 
nodes. The latter is constructed using 200 common meanings and provides the percentage of words between dominant languages spoken in each country-pair which originate from the same ancestor word (the so-called "cognate words"). Measures of distance between populations are often based on dominant groups. Yet, most countries are highly heterogeneous and to better determine the expected distance between two randomly selected individuals, we use genetic, religious and linguistic distances weighted by the share of sub-population belonging to each distinct ancestral, religious or linguistic group in each country (see Spolaore and Wacziarg, 2009). Moreover, we use the same transformation such that distance is bounded by 0 and 100.7 Table 1 contains the summary statistics.

[Table 1 in here]

\section{Empirical strategy}

We estimate the effect of increased immigrants on local security spending using standard panel data regressions with fixed effects. The baseline empirical model is specified as follows:

$$
s_{i t}=\gamma m_{i t}+\beta_{k}^{\prime} x_{i t}+f_{i}+f_{t}+\varepsilon_{i t}
$$

where $s_{i t}$ is the share of public spending devoted to security and $m_{i t}$ is the share of immigrants over the total population in municipality $i$ and year $t . x_{i t}$ is the vector of control variables that includes the population size and density, the share of $65+$, per capita personal income tax base, and a binary variable indicating whether a municipality has to comply with the domestic stability pact. $f_{i}$ and $f_{t}$ are the municipality and year fixed effects and $\varepsilon_{i t}$ is the error term. Our main parameter of interest is $\gamma$ and describes the relationship between the share of immigrants and local spending on security. We report robust standard errors clustered at the municipality level throughout the analysis, in order to control for arbitrary group-wise heteroskedasticity and serial correlation.

Immigrants might sort themselves among municipalities and this self-selection will bias the estimation of the effect of immigration on security spending. For example, if immigrants are less likely to settle in areas where negative attitudes towards them prevail, which in turn can lead to more resources devoted to police, the OLS estimates of $\gamma$ will be biased towards zero. This issue of endogenous immigrants settlement has long been a concern in the literature and it is usually mitigated by using an instrumental variables approach, as long as an exogenous instrument is available. In the absence of a natural experiment in location decision, a typical strategy followed in several recent studies relies on the so-called shift-share instrument, which is built by interacting the national inflows of migrants by country of origin with immigrants' previous geographic distribution. The rationale behind this instrument is that aggregate outflows of migrants are influenced by push factors in the country of origin, and, after leaving, immigrants settle in enclaves established by earlier migrants from the same country of origin. One underlying assumption is that pull factors that attracted immigrants in the past are uncorrelated with current local demand shock (see Altonji and Card, 1991; Card, 2001). In this paper,

\footnotetext{
${ }^{7}$ The correlations among the above distances are not large, ensuring that they account for some distinct element of culture, that are not captured by the remaining measures.
} 
we use a variation of this approach by introducing a novel shift-share instrument. In particular, we exploit changes in the inflow of migrants prompted by the Enlargement of the European Union (EU). Over the period 2003-15, the EU has expanded three times and accepted 13 new Member States to the Union. In a similar vein, Mastrobuoni and Pinotti (2015) exploit exogenous variation in the status of immigrants following the 2007 European Union enlargement to estimate its effect on immigrant crime 8 In fact, the Czech Republic, Cyprus, Estonia, Hungary, Latvia, Lithuania, Malta, Poland, the Slovak Republic and Slovenia joined the EU in 2004. Romania and Bulgaria became EU members in 2007; and Croatia joined up in 2013. Throughout the period, and particularly around the specific dates of accession (2004, 2007 and 2013), the EU witnessed large population movements. The principle of free movement, that gives EU citizens the right to reside and work in any other EU country, promoted larger migration flows particularly from "new" to "old" Member States. This pattern was also prominent in Italy and clearly visible in Figure 2, where we report the size of migration flows to and from Italy over the period 2000-2015. While outflows increased almost linearly over this period, immigration jumped in 2003 and 2007, around the "Eastern enlargement".

$$
\text { [Figure } 2 \text { in here] }
$$

As we want to leverage the aggregate variation in migration produced by the EU enlargement, we build on Docquier et al. (2016) and Ortega and Peri (2014) and estimate the total number of immigrants in Italy stemming from countries that joined the EU in the period 2003-15 through a gravity model of migration. This model exploits cross-country differences in migration flows imputable to migration costs. Such costs are approximated by bilateral geographic and cultural characteristics. The gravity model considers immigrants from all countries of origin and takes the following form:

$$
\log m_{i j t}=\delta^{\prime} w_{i j t}+\lambda^{\prime} \text { distance }_{i j} f_{t}+f_{j}+f_{t}+\epsilon_{i j t}
$$

where $j=1, ., 189$ is the country of origin of immigrants, $i=$ Italy and $t=2003, ., 2015$. This model controls for a number of exogenous variables which capture shocks in the country of origin, and which are thus unlikely to be correlated with unobserved demand factors in the host country. In particular, the vector $w_{i j t}$ includes geographic contiguity, the presence of a common language, the log of the country of origin's population, the capital-to-capital distance, the log of $j$ 's area and a dummy equal to one if $j$ is an European country. Moreover, we exploit the panel dimension of the data and include country $\left(f_{j}\right)$ and year $\left(f_{t}\right)$ fixed-effect and interactions between capital-to-capital distance and year dummies. These additional variables capture changes in transportation and communication costs over time. Finally, $\epsilon_{i j t}$ is the error term.

From model 2 we compute $\widetilde{m}_{e t}$, the annual predicted number of immigrants stemming from the countries that joined the EU in the period 2003-15, where $e=1, ., 13$ is the new EU Member States. yearly number of (predicted) migrants from EU Member States. We then apportioned these (predicted) national figures to municipalities using the settlement of immigrants by country of origin in municipality $i$ in 2003 . Year 2003 is the earliest period in which disaggregated data on migration stocks by country of origin are

\footnotetext{
8 Moriconi et al. (2018) also find that variation in the flows of immigrants in the EU post-2007 is very important and mainly due to the EU enlargement.
} 
available. The resulting quantity is the weighted average of the national predicted inflows of immigrants from new EU Member States, with weights, $\sigma_{i e 2003}$, equal to the share of immigrants in municipality $i$ in 2003, by country of origin:

$$
\widehat{m}_{e t}=\sum_{i} \sigma_{i e 2003} \widetilde{m}_{e t}
$$

This is the shift-share instrument constructed using a sub-set of countries, the new EU Member States. Finally, we look at when exactly these countries joined the EU, and construct our instrument as the interaction between $\widehat{m}_{e t}$ above and a binary indicator, $\tau_{i t}$, that equals one after the year of accession and zero otherwise. This approach allows us to further isolate the portion of the correlation between immigration and local public spending that is due to the causal effect of immigration prompted by the EU enlargement. The first-stage regression of our instrumental variables strategy reads as follows:

$$
m_{i t}=\phi\left(\widehat{m}_{e t} \times \tau_{i t}\right)+\theta_{k}^{\prime} x_{i t}+f_{i}+f_{t}+\xi i t
$$

The identification of the casual effect of immigration on local public spending relies on two key elements: (i) the exogeneity of migration inflows prompted by the accession of these new Member States to the Union and (ii) the presence of pre-existing ethnic settlements, uncorrelated to local economic conditions, that shape immigrants' location decision.

There are no data on the distribution of immigrants across municipalities prior to 2003. This poses two potential problems. First, we may overestimate the correlation between the endogenous variable and the instrument as immigrants' geographical distribution appears in both variables in 2003. To exclude this possibility, we check whether results are affected by the exclusion of data for 2003, and re-estimate all models over the period 2004-15. As the estimates are virtually the same, we keep data for 2003 in the models presented in the following sections. Second, if the shares of immigrants in 2003 are correlated with local demand shocks, the instrument violates the exclusion restriction assumption as shown by Goldsmith-Pinkham et al. (2018). Borjas (1999a) notes that this violation also occurs if local demand shocks are serially correlated. Jaeger et al. (2018) have also recently argued that current adjustments to past demand shocks can also raise concerns for the validity of the instrument. We address these concerns in three ways: (i) we follow Moriconi et al. (2018) and test for the correlation between the instrument and past economic and demographic trends over the period 1991-2001; (ii) we use the share of immigrants in 1936, which is sufficiently distant in time, as suggested in Jaeger et al. (2018); (iii) we use an alternative instrument, the share of votes for the National Fascist Party (PNF) in 1929 Italian general election, which is a proxy for the historical level of openness of a territory towards foreign-borns. These checks are discussed in depth in section 6 . Note that recent waves of immigration caused by the EU enlargement - the exogenous variation we leverage to identify the causal effect of immigration on security spending - are in fact unlikely to be correlated with previous local conditions that attracted immigrants in the first place and to local public spending. 


\section{Estimation results}

In this section we investigate whether public spending on security is affected by changes in the population of foreign-born residents. We first treat immigrants as homogeneous population, and then we use information on the source countries of immigrants for each municipality-year. Having established our main result, we turn to the transmission channels and explore why immigration affects security spending. To render fine-grained explanations, we will break up the original relation into a series of specific questions.

\subsection{Preliminaries}

We begin with Table 2, where we explore different specifications of the model in equation (1). Model in column (i) only comprises our main explanatory variable and the time and unit fixed effects, while omitting the control covariates. Model in column (ii) includes the covariates: population size and density, the share of $65+$, the average income, the presence of the domestic stability pact, as well as year and municipality fixed effects. Column (iii) excludes the provincial capitals, which are arguably the most important Italian municipalities. Column (iv) takes into account voting methods in local elections, and excludes municipalities below 15,000 inhabitants as they use a single round system, whereas above this threshold they adopt a runoff system. Bordignon et al. (2016) find that under single round system, extremist voters play a larger role and policy volatility is also higher, which can make the budget process more complex to determine. Column (v) excludes the five regions with special status, Sardinia, Sicily, Trentino-Alto Adige, Aosta Valley and Friuli-Venezia Giulia, given their degree of administrative and financial autonomy. Finally, column (vi) excludes migrants from the top 5 countries of origin, Romania, Morocco, Albania, China and Ukraine. The results in Table 2 show a positive and statistically robust effect of immigration on the share of local government spending devoted to security. The size of the coefficient is remarkably similar across models, and if for purely illustrative purposes one interprets these OLS estimates as causal, then according to them a one percentage point increase in the share of migrants leads to an increase in the share of security spending in the range of 0.02 to 0.06 percentage points.

Table A.1 provides further insights into the relation between immigration and the composition of local public spending.9 Three basic results emerge: first, immigrants are associated with a decline in per-capita revenues, given their relatively lower fiscal contribution. As a result, they are also associated to lower total local spending. Second, turning to the different categories of municipal spending, more spending on security corresponds to fewer resources available to support culture, sport and tourism as well as local economic activities. Important functions, such as administration, and the provision of essential public services, such as transport, remain unaffected. Third, public spending on welfare also increases as a consequence of higher shares of immigrants. This is interesting per se, as the question of whether immigrants are a significant burden to the welfare state in receiving municipalities features prominently in the debate on the consequences of immigration. To sum up, in response to higher immigration, local governments divert their resources away from cultural activities and business support services and towards

\footnotetext{
${ }^{9}$ We refer the interest reader to Section A.2 of the online Appendix for a discussion of how immigration affects local public finance.
} 
more police protection and welfare.

[Table 2 in here]

The omitted-variable bias generated by stable unit-level confounders should be safely handled in the fixed-effect models reported in Table 2, yet the inclusion of municipal fixed-effect do not guard against confounders that are time varying. For example, new immigrants may be less likely to settle in areas where native populations have a more negative attitudes towards them, which may also lead to higher distrust and more resources devoted to security. If this is the case, OLS estimates may be biased towards zero. At the same time, there is also the possibility of causality running both ways as some immigrant groups may be deterred by increased police presence whereas others can be encouraged to settle in areas with higher police visibility. Therefore, in Table 3 we replicate the specifications in Table 2 but we use a two-stage least squares (2SLS) estimator. The instrument is the predicted share of immigrants stemming from countries that joined the EU between 2003 and 2015 as in equation (3) and the first-stage regression is the one described in the equation (4). The last two rows show the first-stage estimates. As expected, we find that the coefficient of migration in the first-stage is positive and significant, and substantially large. The Kleinbergen-Paap F-Statistic is similar to the conventional F-statistic, but takes into account the clustering of the standard errors, and its values are above conventional levels that characterize weak instruments. Turning to our main results, we find that immigration has a substantive, economically relevant, impact on security spending. The amount of spending devoted to local security increases by $0.12-0.30$ percentage points for a one point increase in the share of immigrants. The results hold independent of whether one controls for socio-economic characteristics, suggesting that they tap changes in spending preferences that are not simply a function of local conditions. Recall that security spending is measured as a share of local public spending, and that, according to Table 1, average spending is $4.4 \%$. So even small changes in the number of immigrants can have important consequences for the level of spending on local law enforcement. All coefficients, with the exception of column (vi), where we exclude the top 5 countries of origin, are statically significant at the $1 \%$ level 10

[Table 3 in here]

We verify the above findings with a round of additional checks in Table 4, using the baseline model of column (ii) in Table 3. First, although we use security spending as a share of total spending, we control for the level of grants from the central government (column (i)) to address concerns about the possibility that higher municipal funding could encourage more relative spending on law enforcement. Second, local governments generate most of the revenue from property taxes, but they also rely on fines and fees collected by law enforcement. As local governments may have incentives to allocate more resources to policing when they collect large amounts of fees and charges, we explicitly control for their value in column (ii). Third, as local governments often cooperate on a variety of issues and the supply of public services can create spatial spillovers (e.g.,

\footnotetext{
${ }^{10}$ The result of the last model in column (vi) is not surprising since an important portion of the overall variation of our instrument is due to immigrants from Romania which, at the same time, is also one of the top 5 countries of origin.
} 
López et al., 2017; Ferraresi et al., 2018), we control for the share of security spending in neighboring municipalities, i.e., the spatial lag, to soak up spatial correlations (see column (iii)). Overall, our results hold up remarkably well to this series of specification checks and the coefficients of share of migrants are almost unchanged. Interestingly, grants from the central government decreases the share of the budget allocated to security as they are usually used to increase funding for other services such as the maintenance of roads. As such, both the spatial lag as well as the amount of fees and charges collected by the police are associated to higher spending on law enforcement.

[Table 4 in here]

\subsection{Heterogeneity}

We now shift the focus towards the "types of migrants" that drive the impact of migration on local public finances and explore whether the change in composition of public spending, in particular the growth in security spending, differs according to the country of origin of immigrants. The dichotomization between natives and immigrants does not comprehensively capture the cultural diversity that may exist across and within such population groups. The cultural distance between social groups is likely to be a core driver of locals' negative attitudes and prejudice towards immigrants as well as concerns about insecurity and national cohesion (see e.g., Citrin et al., 1990). To overcome this limitation, we construct a simple measure of the distance between the immigrants and the host society, Italy, as follows: assume that immigrants in municipality $m$ stem from countries $n=1 \ldots N$. Denote by $\pi_{n m}$ the share of immigrants from a country $n$ in municipality $m$, and by $d_{n}$ the cultural distance between populations $n$ and Italy in municipality $m$. The weighted cultural distance between countries $n$ and Italy in municipality $m$ is then:

$$
W C D_{m}=\sum_{i=1}^{N}\left(\pi_{n m} \times d_{n}\right)
$$

In other words, for every municipality we sum up the dyadic distance between each subpopulation of immigrants and Italy, weighted by the proportion of immigrants belonging to each country of origin. As we discussed in Section 3, we rely on three proxies of cultural distance: genetic, linguistic and religious. Results are shown in Table 5 and are obtained from 2SLS regressions, where the instrument is the predicted weighted cultural distance, constructed as the sum of the dyadic distance between immigrants and Italy, weighted by the predicted share of immigrants from new EU Member States as in equation (3) and multiplied by the indicator for post-accession period. To facilitate the interpretation of results we normalised the indicators, so that their values range from 0 to 100. Findings suggest that the greater the distance between migrants and native, the larger the increase in security spending. In terms of point estimates, we find that one point increase in the genetic distance leads to an increase in security spending of about 0.20 percentage points. Smaller effects are found if other measures of distance are used, with the effect being the smallest for religious distance (about 0.05 percentage points). The effect of linguistic distance ranges between 0.06 and 0.12 percentage points. Taken together, these results suggest that the cultural proximity of foreign-born individuals to 
native populations matters, and the relation between immigration and security spending is more pronounced as the cultural distance between migrants and natives increases.

[Table 5 in here]

As noted in the previous section, municipal spending on security is correlated with the number of police officers. As one would expect, then, when we use the number of police officers as the dependent variable we find that higher shares of immigrants, as well as their cultural distance from the natives, lead municipalities to deploy additional police officers (see Table 6). The effect is quantitatively large, statistically significant, and robust. A ten-point increase in the share of immigrants results in the deployment of two additional police officers. This is a quite large effect, if we consider that the average number of police officers in a municipality is approximately equal to five. The magnitudes of the coefficients are similar when we factor in the heterogeneity of the migrant population.

[Table 6 in here]

\section{Robustness checks}

We probe the robustness of our empirical findings with a variety of alternative specifications and robustness checks. We omit tables due to space limitations, although the additional models can be found in the online Appendix.

The "past-settlement" or "enclave instrument", a Bartik-like instrument introduced by Altonji and Card (1991), is a very popular tool that several studies have used to identify the causal impact of immigration on a variety of outcomes. The instrument generates variation in local migration over time due to the interaction between the immigrant composition of a place and aggregate immigration flows from origin countries. The validity of the instrument is premised on that both components should be uncorrelated, or less correlated, with current factors affecting budget decision. To demonstrate its validity, particularly with regards to the first component, the previously established immigrants settlement (Jaeger et al., 2018; Goldsmith-Pinkham et al., 2018) we carry out two checks. First, as persistent local conditions can affect both immigrants location decision and public spending, we follow Moriconi et al. (2018) and test the correlation of the instrument with economic and demographic trends at the municipality level over the period 19912001 in Table A.2. Results show that there are no pre-trend correlations, which mitigate concerns about correlation between the instrument and past demand shock. Second, as immigration composition in year 2003 may not be sufficiently distant in time, we use the share of immigrants obtained from Census in 1936 11 or the share of votes for the National Fascist Party (PNF) in 1929 Italian general election as a source of cross-sectional variation. Unfortunately these information are only available at the province level. Thus, we first replicate the main models of Tables 2 and 3 , using the province, rather than the municipality, as unit of observation, to make sure that our previous findings about immigration and local spending are borne out by this new panel data structure. The results

\footnotetext{
${ }^{11}$ Other available Census data are for 1951 and 1961. However, we do not use them in the analysis because they record a fewer number of origin countries, thereby they fall short of appropriately explaining local variation in immigrants later in the 2000s.
} 
are qualitatively the same and can be found in Table A.3, columns (i) and (ii). In column (iii) we replace migrants distribution in 2003 with the corresponding distribution in 1936 . As we can see, the coefficients in columns (ii) and (iii) are remarkably similar, which increases the confidence in our results. However, the 2SLS regression in column (iii) seems to be affected by weak instrument, as evidenced by the small value of the F-stat. This is a known drawback of using distant distribution of immigrants in shift-share-like strategy, which reduces the predictive power of the instrument. Finally, in column (iv) we exploit variations in the share of votes approving the list of deputies appointed by the Grand Council of Fascism. Since this instrument only varies across provinces, the second-stage regression is estimated in changes over the period 2003-15. Specifically we estimate a model of the following form: $\Delta s_{p}=\gamma \Delta m_{p}+\beta_{k}^{\prime} \Delta x_{p}+\Delta \varepsilon_{p}$, and we instrument the change of immigrants, $\Delta m_{p}$, with the share of votes for PNF. Although only a minority of citizens, less than $2 \%$, voted against, the number of "No" captures the degree of opposition against the regime. The proportion of "No" across provinces ranges from $10 \%$ in the province of Bolzano, Trento and Milano to almost zero in Matera, Lecce and Cosenza. As the National Fascist Party had very strong anti-immigration and anti-integration stances towards minority groups that were deemed inferior, we use this variation as a proxy for the historical level of openness of a province towards foreign-borns. In fact, higher shares of approval for the list of deputies appointed by the Grand Council of Fascism correspond to lower shares of immigrants in the first stage. In the second stage, we find that immigration does indeed increase spending on security, and the coefficients are again very similar to those in columns (i) to (iii).

\subsection{Alternative instruments}

A fair concern with the instrument presented in section 4 is that this is based on a subset of nationalities. This may pose issues if, for example, immigrants from the excluded nationalities have a higher propensity to move to municipalities with more positive attitudes towards them. If this is the case, the impact of migration on security spending would be over-estimated. To address this issue, we consider an additional instrument that exploits variation in migration inflows due to immigrants stemming from all world countries through the period 2003-15. We replicate the analysis of Table 3 but we use this alternative instrument, obtained from the gravity model of migration in equation (2). As we can see in Table A.4. model (i), a one percentage point increase in immigrants leads to an increase in security spending of about 0.35 percentage points. The coefficients are overall substantially large, ranging from 0.21 to 0.39 , which suggest that the estimates in Table 3 may be a lower estimate of the strength of the immigration-security spending relationship. If anything, focusing on a subset of EU nationalities does not affect the main results.

The correlation between the instrument and the endogenous variable must be high in order to reduce finite-sample bias. The F-stat is generally used to gauge the size of the distortion of the IV estimator. As we have seen in the previous section, the F-stat is in all cases above the threshold value of 10, indicating that the coefficient of the excluded instrument is different from zero in the first-stage regressions. Since our instrument is the interaction of the shift-share variable and the indicator for post-accession period, part of the correlation between the instrument and the endogenous variable could be 
attributable to the latter rather than be driven by previous settlement of immigrants. To exclude this possibility, we re-estimate all 2SLS models of Table 3 using the shift-share variable of equation (3) without interacting it with the post-accession dummy. Therefore, the instrument is the predicted share of immigrants stemming from the countries that joined the EU between 2003 and 2015, which is exactly equation (3). Results of this exercise are reported in Table A.5 and are very similar to those of Table 3, thus further corroborating our evidence of a strong effect of migrants on security spending. Moreover, the F-stat is well beyond the value indicating weak instruments. In sum, the interaction of the shift-share with the post-accession dummy does not drive our main conclusions.

\section{Mechanisms}

\subsection{Does immigration increase crime?}

We now investigate why the presence of foreign population leads to an increase in local spending on security. A seemingly obvious candidate is the crime rate as foreign nationals may either commit more crimes or lead to higher crime rates among native-born citizens. Were it the case, we would observe a positive relationship between crime rate and migrants, which in turn would translate into an increase in security spending. Hence, we collect data on the number of all registered crime per capita from ISTAT. These data are only available at the provincial level. We then build a panel of 93 Italian provinces over the period 2003-2015 including the same financial, demographic and economic data of the previous tables and investigate whether the presence of immigrants is linked to an increase in crime $\sqrt{12}$ Results of this analysis are reported in Table 7 and do not support the idea that an increase immigrants is correlated with an increase in crime. Overall, migrants are not significantly associated to crime (column (i)), also when we control for security spending (column (ii)). As such, we also exclude the possibility that immigration, by increasing security spending, indirectly reduces crime. And none of the weighted cultural distances between immigrants and the native population are statistically significant at conventional levels (models (iii) to (vi)). Taken together, these results mirror previous studies that find no empirical relationship between immigration and the overall crime rate in Italian provinces (see e.g., Bianchi et al., 2012, who however uses data for the period 1990-2003, whereas our sample starts in 2003).13

[Table 7 in here]

\subsection{Does immigration increase fear of crime?}

In the previous section, we found that the number of immigrants can give rise to increased public spending on security. In a similar vein, higher cultural distances between home and host countries lead to more spending on law enforcement. We also found that

\footnotetext{
${ }^{12}$ Crime records are not available for year 2009 and we imputed these missing values by using linear interpolation.

${ }^{13}$ Our data allows us to distinguish between several major crime categories such as homicide, robbery, theft, and drug-related crimes. We do not find evidence of a significant effect of migration on any typology of crime. We omit these additional tables from the presentation, but the results can be replicated with our data material.
} 
immigrants are not associated to increased insecurity. In this section, we evaluate an alternative explanation to the crime mechanism: immigration may just increase worry about crime. To get as close as possible to the migration variables of previous models, we look at whether respondents live in a neighborhood where people from different race or foreign-born people are present. In more detail, we use survey data from the World Value Surveys (WVS) ${ }^{14}$ and select only respondents living in Italy. We employ the integrated data files of one round of the WVS covering the period 2005-2009.15 The first outcome variable is based on the WVS survey question on "[w] hat the aims of this country should be for the next ten years [... ] Would you please say which one of these you, yourself, consider the most important?" Possible answers include "A stable economy", "Progress toward a less impersonal and more humane society", "Progress toward a society in which ideas count more than money", "The fight against crime". We first deleted all individuals who have not responded to this question before transforming this item into a binary variable capturing worry about crime. Thus, the variable takes on the value of one if "The fight against crime" is declared as the first choice by the respondent, and zero otherwise. The second outcome variable is based on the question "Immigrants increase crime problems". Individuals could reply on a scale from 1 to 10 with lower values standing for more concerns about immigrants and crime. In this case too, we transform the variable into a binary indicator, and to select the most concerned individuals we give one for any reported value below (or equal to) 3 and zero otherwise. ${ }^{16}$ Table 8 shows our models, which include a battery of individual-level socio-economic and demographic characteristics. We find that respondents living in close proximity to ethnically diverse neighbors or foreign-born individuals are more likely to suggest that fighting crime is indeed the main priority of the country. At the same time, both the birthplace of the neighbors and the ethnic background increase the level of concerns about immigration leading to higher crime rates. In particular, our results indicate that the probability of declaring the fight against crime as the priority of the country increases by $8 \%$ and $13 \%$ if the respondent's neighbors are of different racial backgrounds or are foreign-born, respectively. In a similar vein, the probability of reporting concerns about immigrants and crime increases when respondents live in a neighborhood where people from different race $(14 \%)$ or foreign-born people $(17 \%)$ are present.

\section{[Table 8 in here]}

\subsubsection{Does immigration erode social capital?}

To delve deeper into the underlying mechanism, we ask why fear of crime should increase with immigration flows. A wealth of studies, mostly in criminology, has consistently found that trust and social cohesion in neighborhoods are strongly associated to, and can help predict, fear of crime (see e.g., Bennett, 1991; Sampson et al., 1997; Swatt et al., 2013; Markowitz et al., 2001; Rader, 2017). We focus specifically on social capital, defined as the "features of social organization, such as trust, norms, and networks, that

\footnotetext{
${ }^{14}$ http://www. worldvaluessurvey.org/wvs.j.sp

${ }^{15}$ This time span is the only one for which information on the outcome variables we are interested in are available for Italy.

${ }^{16}$ Note that results do not change if the categorical scale is used in lieu of the binary indicator. This additional table can be produced with our replication material.
} 
can improve the efficiency of society by facilitating coordinated actions" (Putnam et al., 1994 p. 167) 17 There is a normatively sympathetic component in its definition and scholars have thus not surprisingly developed an impressive body of research suggesting that trust and social networks allow individuals, companies, and nations to flourish (Putnam, 2000; Guiso et al., 2004; Nannicini et al., 2013; Guiso et al., 2016), 18 There is also a good deal of support for the importance of social networks and cohesion in shaping people's perceptions of their neighborhood. There are two dimensions to social capital: a structural component, which includes the existence and extent of social networks, and a cognitive or attitudinal component comprising trust and reciprocity. We contend that both dimensions are important and related to each other, although they could capture different aspects of social capital and thus exert different effects on public beliefs and fear of crime, and on individual demand for security (see e.g., Liska and Warner, 1991; Buonanno et al., 2009; Brunton-Smith et al., 2014; Sargeant et al., 2017). ${ }^{19}$

To investigate this hypothesis, in Panel A of Table 9 we first use the number of percapita non-profit organizations, a proxy for the structural component, using municipal data from the 2001 and 2011 Census.20 We can see that an increase in the share of migrant is associated to a reduction in the number of per-capita non-profit organizations (column (i)) even though the magnitude of its impact is small. Similarly, high linguistic distances between native and foreign-born residents are associated to a significant decrease albeit small in the number of organizations (columns (iii)-(iv)).

In panel B of Table 9 we use survey data from the World Value Surveys (WVS). The outcome variable for the attitudinal component is based on the question "Generally speaking, would you say that most people can be trusted or that you need to be very careful in dealing with people?" Possible answers include "Most people can be trusted", "Need to be very careful". We aggregate three waves (1990-1994, 1995-1998 and 20052009) for which information for Italy are available. For the structural component, we follow Knack and Keefer (1997) and use responses to a question about whether each of the following behaviors "can always be justified, never be justified or something in between" : (i) "claiming government benefits which you are not entitled to"; (ii) "avoiding a fare on public transport"; (iii) "cheating on taxes if you have the chance". We sum values over the five items to create a scale indicating the strength of civic norms ${ }^{21}$ Larger values of this indicator indicate greater civic cooperation.

Our results suggest that individuals with foreign-born neighbors or neighbors of difference race are more likely to report low levels of trust toward other members of the

\footnotetext{
17 Guiso et al. (2016, p.1406) defines social capital as the "persistent and shared beliefs and values that help a group overcome the free rider problem in the pursuit of socially valuable activities" and label it "civic capital".

18 Putnam et al. (1994) pioneered the research on social capital and institutional outcomes when he found that local government quality across regions in Italy improves with higher levels of social capital, measured by civic engagement.

${ }^{19}$ Furthermore, previous studies have relied to a large extent either on self-reported perceptions of trust, or on actual measures of the structural component, while we use both subjective and objective indicators.

${ }^{20}$ Data on immigration in 2001 are not available and therefore we use the earliest year accessible which is 2003. $\beta$ coefficients in Panel A of Table 9 are multiplied by 1000 .

${ }^{21}$ Knack and Keefer (1997) also consider other two additional variables, that is "keeping money that you have found" and "failing to report damage you've done accidentally to a parked vehicle". Unfortunately, these two indicators were not available for the 1999-2009 waves.
} 
society. Similarly, having neighbors of different race or foreign-born neighbors is negatively correlated with civic cooperation within societies. In terms of substantive effect, the probability of trust into social interactions decreases by $11-12 \%$. In addition, the presence of neighbors of different race or born in another county is associated with a reduction in our measure of civic cooperation of almost one point on a scale between 0 and 27 .

[Table 9 in here]

\section{Extensions}

In this final section, we present some additional insights into the mechanism underpinning the relation between immigration and spending on law enforcement. First, if immigration leads to fear of crime and increasing demand for police presence, then the electorate should at least partially express this demand by voting for right-wing parties. Immigrants can affect the voting behavior of the electorate and there is a positive relationship between immigration and vote shares for right-wing parties, as they are less supportive of multi-ethnic societies and often appeal to anti-immigration sentiments (Barone et al., 2016; Halla et al., 2017; Brunner and Kuhn, 2018). At the same time, the political economy literature has long argued that government ideology influences public expenditure and left-wing and right-wing governments usually place emphasis on different budget positions with a view to gratifying their electorate. Right-wing politicians attach more importance to law and order and are more likely to allocated resources to security-related policies (Van Dalen and Swank, 1996; Whitten and Williams, 2011; Bove et al., 2017). Parties of the right could push for increased allocations to "guns", also in an attempt to convince their rational, well-informed voters that they share their spending priorities (Drazen and Eslava, 2010). We construct a dataset of mayoral elections in Italy over the period 2003-2015 in municipalities with more than 15,000 residents, as below this threshold the electoral system prevents us from clearly identifying the candidates' party affiliation. Following Barone et al. (2016), we estimate linear probability models where the dependent variable is a dummy variable taking value one if the political color of the mayor switches from center-left to center-right and zero otherwise. Since population data are recorded as of $31^{\text {st }}$ of December and municipal elections are held before that date, in our regression models we take the one-year lag of the share of migrants and cultural distance indicators. Table A.6 shows our estimates: we find that one percentage point increase in the share of immigrants is associated to an increase of the probability that the municipality switches to a right-wing mayor by 3 percentage points (see column (i)). Higher cultural distances between immigrants and local populations also lead to an increase in the support for anti-immigration parties (see column (ii-v)).

\section{Conclusions}

Our empirical analysis of immigration and public spending on law enforcement in Italian municipalities provides straightforward but important results. First, immigration leads to an increase in public spending for police protection, at the expense of the budget allocated to other important functions, such as culture, tourism or local economic development. Second, when taking into account the rich diversity within migration flows, and 
between immigrants and native populations, we find that the effect is larger the higher the cultural distance between immigrants' countries of origin and their destination state. Third, a higher crime rate is not the primary source of our findings. Instead, we show that this is likely to be explained by an increase in people's fear of future crimes, as opposed to the actual probability of being a victim of crime. We also provide evidence to suggest that immigration is associated to a deterioration in the strength of social ties and interpersonal trust, two contextual factors that are shown to predict fear of crime and increase the demand for police services. Whereas fear of crime is stronger in communities with weak community bonds, social cohesion and trust among community members cause residents to feel safer and less afraid of crime. Our results are robust across a number of measures of social capital, different markers of cultural distance, and distinct instrumental variables approaches, including the use of historical data.

Immigrant populations in Europe have been growing fast for decades now. Crime in the same period, however, has moved in the opposite direction, with the rate of violent crimes in many countries well below what it was in 90s. Yet, political parties in Hungary, Austria and Italy have won election after campaigns based on exploiting and whipping up fears about the impact of immigration on crime. Similarly, worry about violent crime has lead to the political success of anti-immigration parties at the local level. This can have important consequences for a municipality's determination of short and long term priorities and which local services to fund. A large literature documents how immigration leads to preferences for public spending, but predominately focuses on the size of government. This has displaced attention from the mechanisms through which immigrants are associated with changes in the composition of government budgets, particularly at the local level. Our knowledge of the relation between migration and public spending on police protection is particularly anecdotal and current research remains silent on why, how, and under which circumstances an increase in immigration may affect security spending. We find that municipal spending on security increases by $0.12-0.30$ percentage points for a one point increase in the share of immigrants. Italian cities have long struggled to afford the cost of basic infrastructure maintenance and to provide vital services. In fact, a growing number of municipalities are identified every year as being in financial distress. Therefore, the estimated magnitudes of this relationship are not only statistically significant but also economically meaningful. Despite the size of global migration at the present time, and a lack of adequate state responses to address complex demographic landscapes, our knowledge of the impact of immigration on public perceptions and public spending is still quite limited. The present article contributes to our understanding of the consequences of immigration for the receiving municipality's fiscal position, which is crucial for effective public policy making. 


\section{References}

Alesina, A., Baqir, R., and Easterly, W. (1999). Public goods and ethnic divisions. The Quarterly Journal of Economics, 114(4):1243-1284.

Alesina, A. and Glaeser, E. L. (2004). Fighting poverty in the US and Europe: A world of difference. Oxford University Press.

Altonji, J. G. and Card, D. (1991). The effects of immigration on the labor market outcomes of less-skilled natives. In Immigration, trade, and the labor market, pages 201-234. University of Chicago Press.

Arrow, K. J. (1972). Gifts and exchanges. Philosophy and Public Affairs, 1(4):343-362.

Barone, G., D'Ignazio, A., de Blasio, G., and Naticchioni, P. (2016). Mr. rossi, mr. hu and politics. the role of immigration in shaping natives' voting behavior. Journal of Public Economics, 136:1-13.

Bell, B., Fasani, F., and Machin, S. (2013). Crime and immigration: Evidence from large immigrant waves. Review of Economics and statistics, 21(3):1278-1290.

Belmonte, A., Dell'Anno, R., and Teobaldelli, D. (2017). Tax morale, aversion to ethnic diversity, and decentralization. European Journal of Political Economy.

Bennett, T. (1991). The effectiveness of a police-initiated fear-reducing strategy. The British Journal of Criminology, 31(1):1-14.

Bianchi, M., Buonanno, P., and Pinotti, P. (2012). Do immigrants cause crime? Journal of the European Economic Association, 10(6):1318-1347.

Boeri, T. (2010). Immigration to the land of redistribution. Economica, 77(308):651-687.

Boeri, T., De Philippis, M., Patacchini, E., and Pellizzari, M. (2015). Immigration, housing discrimination and employment. The Economic Journal, 125(586).

Bonifazi, C., Heins, F., Strozza, S., and Vitiello, M. (2009). The italian transition from an emigration to immigration country, citizens and governance in knowledege-based society. IDEA Working Papers, (No. 5, March 2009).

Bordignon, M., Nannicini, T., and Tabellini, G. (2016). Moderating political extremism: single round versus runoff elections under plurality rule. American Economic Review, 106(8):2349-70.

Borjas, G. J. (1999a). The economic analysis of immigration. In Ashenfelter, O. and Card, D., editors, Handbook of Labor Economics, volume 3. Elsevier.

Borjas, G. J. (1999b). Immigration and welfare magnets. Journal of labor economics, 17(4):607-637.

Bove, V., Efthyvoulou, G., and Navas, A. (2017). Political cycles in public expenditure: Butter vs guns. Journal of Comparative Economics, 45(3):582-604.

Brunner, B. and Kuhn, A. (2018). Immigration, cultural distance and natives' attitudes towards immigrants: Evidence from swiss voting results. Kyklos, 71(1):28-58.

Brunton-Smith, I., Jackson, J., and Sutherland, A. (2014). Bridging structure and perception: On the neighbourhood ecology of beliefs and worries about violent crime. British Journal of Criminology, 54(4):503-526.

Buonanno, P., Montolio, D., and Vanin, P. (2009). Does social capital reduce crime? The journal of law and economics, 52(1):145-170.

Card, D. (2001). Immigrant inflows, native outflows, and the local labor market impacts of higher immigration. Journal of Labor Economics, 19(1):22-64. 
Card, D., Dustmann, C., and Preston, I. (2012). Immigration, wages, and compositional amenities. Journal of the European Economic Association, 10(1):78-119.

Cavalli-Sforza, L. L., Menozzi, P., and Piazza, A. (1994). The history and geography of human genes. Princeton University Press.

Citrin, J., Reingold, B., and Green, D. P. (1990). American identity and the politics of ethnic change. The Journal of Politics, 52(4):1124-1154.

Dahlberg, M., Edmark, K., and Lundqvist, H. (2012). Ethnic diversity and preferences for redistribution. Journal of Political Economy, 120(1):41-76.

Desmet, K., Weber, S., and Ortuño-Ortín, I. (2009). Linguistic diversity and redistribution. Journal of the European Economic Association, 7(6):1291-1318.

Docquier, F., Lodigiani, E., Rapoport, H., and Schiff, M. (2016). Emigration and democracy. Journal of Development Economics, 120:209 - 223.

Drazen, A. and Eslava, M. (2010). Electoral manipulation via voter-friendly spending: Theory and evidence. Journal of development economics, 92(1):39-52.

Dustmann, C., Frattini, T., and Preston, I. P. (2012). The effect of immigration along the distribution of wages. Review of Economic Studies, 80(1):145-173.

Dyen, I., Kruskal, J. B., and Black, P. (1992). An indoeuropean classification: A lexicostatistical experiment. Transactions of the American Philosophical Society, pages iii-132.

Fearon, J. D. (2003). Ethnic and cultural diversity by country*. Journal of Economic Growth, 8(2):195222.

Ferraresi, M., Migali, G., and Rizzo, L. (2018). Does intermunicipal cooperation promote efficiency gains? evidence from italian municipal unions. Journal of Regional Science, 58(5):1017-1044.

Friedberg, R. M. and Hunt, J. (1995). The impact of immigrants on host country wages, employment and growth. The Journal of Economic Perspectives, 9(2):23-44.

Fukuyama, F. (1995). Trust: The social virtues and the creation of prosperity. Free Press Paperbacks.

Gerdes, C. (2011). The impact of immigration on the size of government: Empirical evidence from danish municipalities. The Scandinavian Journal of Economics, 113(1):74-92.

Gokmen, G. (2017). Clash of civilizations and the impact of cultural differences on trade. Journal of Development Economics, 127:449-458.

Goldsmith-Pinkham, P., Sorkin, I., and SwiftJaeger, H. (2018). Bartik instruments: What, when, why, and how. NBER Working Paper, (24408).

Guiso, L., Sapienza, P., and Zingales, L. (2004). The role of social capital in financial development. The American Economic Review, 94(3):526-556.

Guiso, L., Sapienza, P., and Zingales, L. (2006). Does culture affect economic outcomes? The journal of economic perspectives, 20(2):23-48.

Guiso, L., Sapienza, P., and Zingales, L. (2009). Cultural biases in economic exchange. Quarterly Journal of Economics, pages 1095-1131.

Guiso, L., Sapienza, P., and Zingales, L. (2016). Long-term persistence. Journal of the European Economic Association, 14(6):1401-1436. 
Hainmueller, J. and Hopkins, D. J. (2014). Public attitudes toward immigration. Annual Review of Political Science, 17.

Halla, M., Wagner, A. F., and Zweimüller, J. (2017). Immigration and voting for the far right. Journal of the European Economic Association, page jvw003.

Jaeger, D. A., Ruist, J., and Stulher, J. (2018). Shift-share instruments and the impact of immigration. NBER Working Paper, (24285).

Knack, S. and Keefer, P. (1997). Does social capital have an economic payoff? a cross-country investigation. The Quarterly journal of economics, 112(4):1251-1288.

Levine, P. B. and Zimmerman, D. J. (1999). An empirical analysis of the welfare magnet debate using the nlsy. Journal of Population Economics, 12(3):391-409.

Light, M. T. and Miller, T. (2018). Does undocumented immigration increase violent crime? Criminology, $56(2): 370-401$.

Liska, A. E. and Warner, B. D. (1991). Functions of crime: A paradoxical process. American Journal of Sociology, 96(6):1441-1463.

López, F. A., Martínez-Ortiz, P. J., and Cegarra-Navarro, J.-G. (2017). Spatial spillovers in public expenditure on a municipal level in spain. The Annals of Regional Science, 58(1):39-65.

Luttmer, E. F. (2001). Group loyalty and the taste for redistribution. Journal of political Economy, 109(3):500-528.

Markowitz, F. E., Bellair, P. E., Liska, A. E., and Liu, J. (2001). Extending social disorganization theory: Modeling the relationships between cohesion, disorder, and fear. Criminology, 39(2):293-319.

Mastrobuoni, G. and Pinotti, P. (2015). Legal status and the criminal activity of immigrants. American Economic Journal: Applied Economics, 7(2):175-206.

Melitz, J. and Toubal, F. (2014). Native language, spoken language, translation and trade. Journal of International Economics, 93(2):351-363.

Moriconi, S., Peri, G., and Turati, R. (2018). Skill of the immigrants and vote of the natives: Immigration and nationalism in european elections 2007-2016. NBER Working Paper, (25077).

Nannicini, T., Stella, A., Tabellini, G., and Troiano, U. (2013). Social capital and political accountability. American Economic Journal: Economic Policy, 5(2):222-50.

Ortega, F. and Peri, G. (2014). Openness and income: The roles of trade and migration. Journal of International Economics, 92(2):231-251.

Ottaviano, G. I. and Peri, G. (2012). Rethinking the effect of immigration on wages. Journal of the European economic association, 10(1):152-197.

Pedersen, P. J., Pytlikova, M., and Smith, N. (2008). Selection and network effects?migration flows into oecd countries 1990-2000. European Economic Review, 52(7):1160-1186.

Peri, G. and Sparber, C. (2009). Task specialization, immigration, and wages. American Economic Journal: Applied Economics, 1(3):135-69.

Pinotti, P. (2017). Clicking on heaven's door: The effect of immigrant legalization on crime. American Economic Review, 107(1):138-68.

Preston, I. (2014). The effect of immigration on public finances. The Economic Journal, 124(580). 
Putnam, R. D. (2000). Bowling alone: The collapse and revival of American community. Simon \& Schuster New York.

Putnam, R. D., Leonardi, R., and Nanetti, R. Y. (1994). Making democracy work: Civic traditions in modern Italy. Princeton university press.

Rader, N. (2017). Fear of crime. In Oxford Research Encyclopedia of Criminology and Criminal Justice.

Razin, A., Sadka, E., and Swagel, P. (2002). Tax burden and migration: a political economy theory and evidence. Journal of Public Economics, 85(2):167-190.

Razin, A. and Wahba, J. (2011). Migration policy and the generosity of the welfare state in europe. DICE Report, 9(4):28.

Sampson, R. J., Raudenbush, S. W., and Earls, F. (1997). Neighborhoods and violent crime: A multilevel study of collective efficacy. Science, 277(5328):918-924.

Samuel, P. (1993). Huntington, the clash of civilizations. Foreign affairs, 72(3):22-49.

Sargeant, E., Liu, Y., St John, N., Fong Hong, N., Huu, T., Chen, J., and Mazerolle, L. (2017). Social capital and fear of crime in brisbane. Journal of Sociology, 53(3):637-652.

Speciale, B. (2012). Does immigration affect public education expenditures? quasi-experimental evidence. Journal of public economics, 96(9):773-783.

Spolaore, E. and Wacziarg, R. (2009). The diffusion of development. Quarterly Journal of Economics, 124(2):469-529.

Spolaore, E. and Wacziarg, R. (2016). Ancestry, language and culture. In The Palgrave handbook of economics and language, pages 174-211. Springer.

Swatt, M. L., Varano, S. P., Uchida, C. D., and Solomon, S. E. (2013). Fear of crime, incivilities, and collective efficacy in four miami neighborhoods. Journal of Criminal Justice, 41(1):1-11.

UN DESA (2017). International migration report. United Nations, Department of Economic and Social Affairs, Population Division.

Van Dalen, H. P. and Swank, O. H. (1996). Government spending cycles: Ideological or opportunistic? Public Choice, 89(1-2):183-200.

Whitten, G. D. and Williams, L. K. (2011). Buttery guns and welfare hawks: The politics of defense spending in advanced industrial democracies. American Journal of Political Science, 55(1):117-134. 


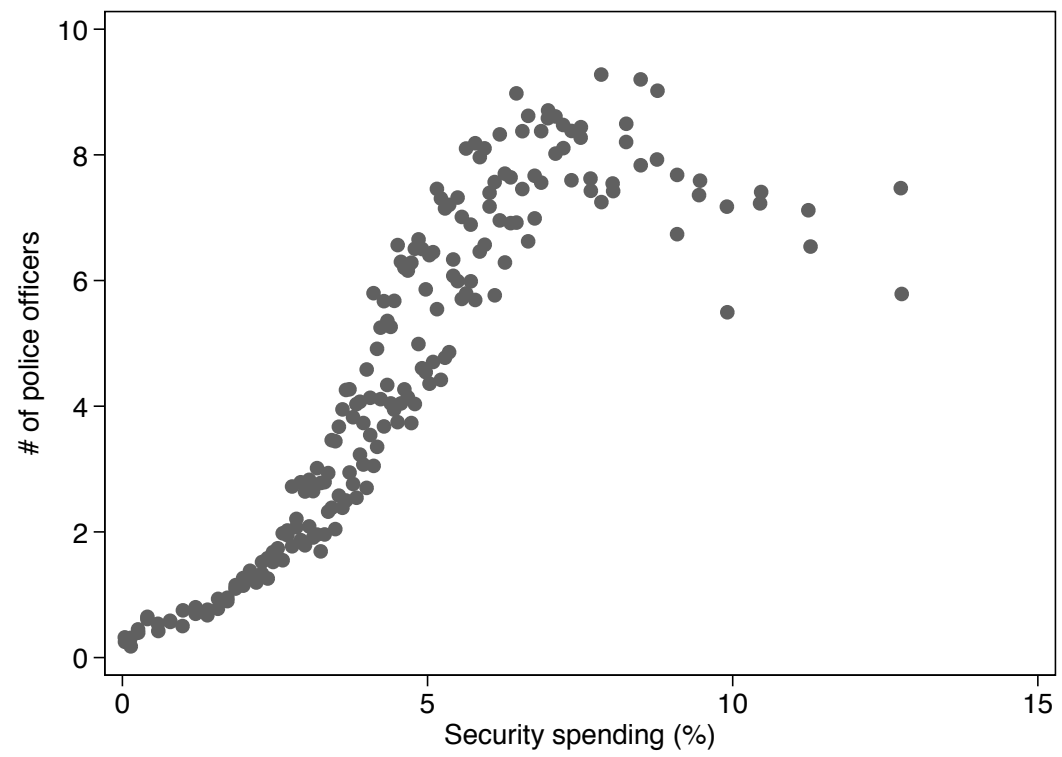

Figure 1: Correlation between spending on security and number of police officers

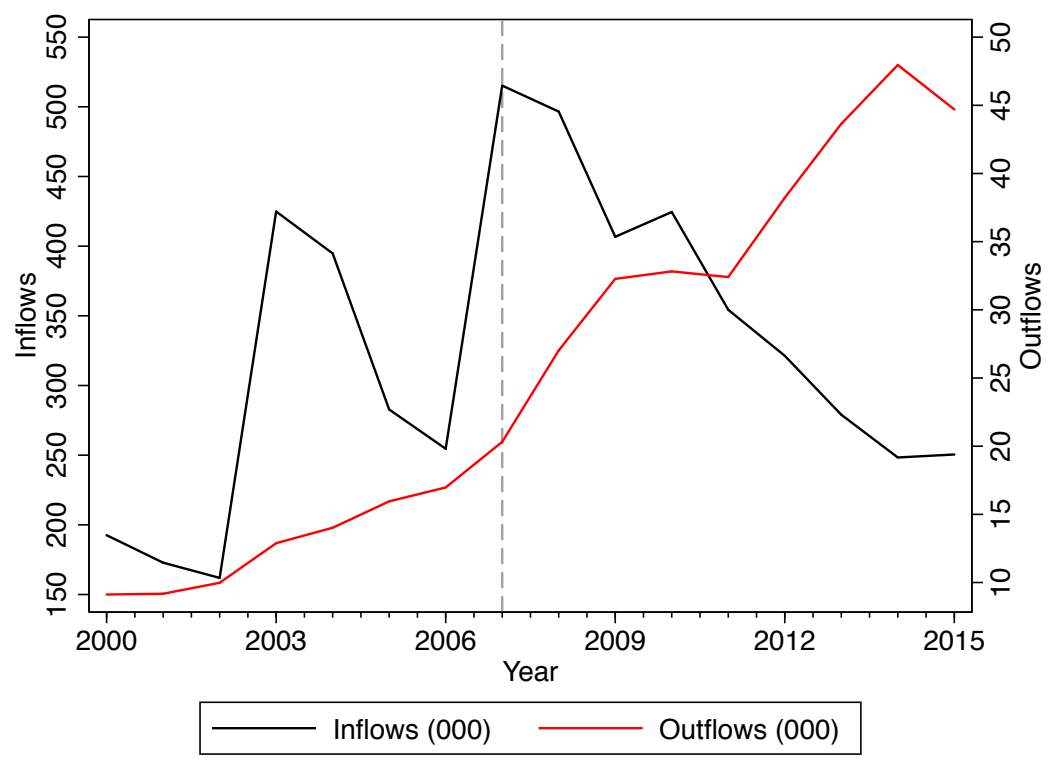

Figure 2: Inflows and outflows of foreign population in Italy, 2003-2015. (Source: OECD) 
Table 1: Summary Statistics.

\begin{tabular}{|c|c|c|c|c|c|}
\hline Variable & Obs & Mean & $\begin{array}{l}\text { Std. } \\
\text { Dev. }\end{array}$ & Min & Max \\
\hline \multicolumn{6}{|l|}{ MUNICIPAL-LEVEL DATA } \\
\hline spending on security (\%) & 94,159 & 4.37 & 3.13 & 0.00 & 46.75 \\
\hline $\begin{array}{l}\text { spending on administration \& management services spend- } \\
\text { ing }(\%)\end{array}$ & 94,159 & 40.06 & 11.57 & 0.00 & 100.00 \\
\hline $\begin{array}{l}\text { spending on roads \& transport services, planning \& envi- } \\
\text { ronment services }(\%)\end{array}$ & 94,159 & 28.80 & 9.50 & 0.00 & 95.15 \\
\hline spending on culture, sport and tourism services (\%) & 94,159 & 4.31 & 3.42 & 0.00 & 69.50 \\
\hline spending social services and education services (\%) & 94,159 & 20.19 & 10.29 & 0.00 & 85.51 \\
\hline spending economic development (\%) & 94,159 & 1.40 & 4.42 & 0.00 & 89.21 \\
\hline revenue & 94,159 & 1034.17 & 760.03 & 62.29 & 37882.98 \\
\hline total spending & 94,159 & 934.91 & 620.09 & 7.80 & 30847.16 \\
\hline surplus & 94,159 & 99.26 & 246.44 & -4577.16 & 33289.64 \\
\hline migrants $(\%)$ & 94,159 & 5.33 & 4.11 & 0.00 & 32.19 \\
\hline population density & 94,159 & 304.61 & 653.99 & 0.73 & 13024.17 \\
\hline share of $65+$ & 94,159 & 0.23 & 0.06 & 0.04 & 0.69 \\
\hline population & 94,159 & 7577.21 & 42817.68 & 34.00 & 2872021.00 \\
\hline domestic stability pact & 94,159 & 0.41 & 0.49 & 0.00 & 1.00 \\
\hline income & 94,159 & 11318.96 & 3361.33 & 1762.21 & 58956.46 \\
\hline$\widehat{\text { migrants }}(\%)(\mathrm{I})$ & 94,159 & 1.09 & 2.14 & 0.00 & 47.47 \\
\hline migrants excluding top 5 senders $(\%)$ & 94,159 & 2.96 & 2.54 & 0.00 & 26.16 \\
\hline migrants $(\%)(\mathrm{II})$ & 94,159 & 5.46 & 4.80 & 0.00 & 49.78 \\
\hline migrants (\%) (III) & 94,159 & 1.34 & 2.19 & 0.00 & 47.47 \\
\hline grants & 86,916 & 338.62 & 478.59 & 0.00 & 37090.55 \\
\hline fees \& charges & 86,916 & 114.25 & 239.71 & 0.00 & 25999.76 \\
\hline security spending $-i(\%)$ & 94,159 & 4.44 & 1.95 & 0.00 & 20.79 \\
\hline WCD (genetic) & 94,159 & 6.91 & 7.11 & 0.00 & 100 \\
\hline WCD (linguistic cognate) & 94,159 & 7.99 & 7.20 & 0.00 & 100 \\
\hline WCD (linguistic common nodes) & 94,159 & 15.02 & 11.64 & 0.00 & 91.52 \\
\hline WCD (religious) & 94,159 & 15.53 & 12.57 & 0.00 & 100 \\
\hline right-wing mayor & 3,780 & 0.29 & 0.46 & 0.00 & 1.00 \\
\hline no. of nonprofit organizations & 13,950 & 0.01 & 0.00 & 0.00 & 0.10 \\
\hline no. of police officers & 67,834 & 5.21 & 9.02 & 0.00 & 85.00 \\
\hline$\widehat{\mathrm{WCD}}$ (genetic) & 94,159 & 2.26 & 4.47 & 0.00 & 100 \\
\hline$\widehat{\mathrm{WCD}}$ (linguistic cognate) & 94,159 & 1.92 & 3.67 & 0.00 & 100 \\
\hline$\widehat{\mathrm{WCD}}$ (linguistic common nodes) & 94,159 & 2.32 & 4.54 & 0.00 & 100 \\
\hline$\widehat{\mathrm{WCD}}$ (religious) & 94,159 & 2.20 & 4.45 & 0.00 & 100 \\
\hline \multicolumn{6}{|l|}{ ProvinCe-LEVEL DATA } \\
\hline crime & 1,209 & 0.04 & 0.01 & 0.02 & 0.09 \\
\hline population & 1,209 & 543806.70 & 614664.30 & 69610.00 & 4182007.00 \\
\hline population density & 1,209 & 269.67 & 369.70 & 38.24 & 2863.54 \\
\hline share of aged & 1,209 & 0.22 & 0.03 & 0.13 & 0.29 \\
\hline income & 1,209 & 12548.53 & 2990.99 & 5934.55 & 19810.86 \\
\hline migrants $(\%)$ & 1,339 & 6.23 & 3.38 & 0.54 & 16.02 \\
\hline migrants $(\%)$ & 1,339 & 1.02 & 1.14 & 0.00 & 6.35 \\
\hline migrants $1936(\%)$ & 1,157 & 1.08 & 3.24 & 0.00 & 31.36 \\
\hline vote-share pro-fascism party (\%) & 88 & 98.57 & 1.66 & 92.98 & 100 \\
\hline WCD (genetic) & 1,209 & 12.48 & 15.04 & 0.00 & 100 \\
\hline WCD (linguistic cognate) & 1,209 & 16.45 & 16.75 & 0.00 & 100 \\
\hline WCD (linguistic common nodes) & 1,209 & 14.47 & 15.75 & 0.00 & 100 \\
\hline WCD (religious) & 1,209 & 14.43 & 15.78 & 0.00 & 100 \\
\hline spending on security (\%) & 1,209 & 5.68 & 1.39 & 0.00 & 9.97 \\
\hline \multicolumn{6}{|l|}{ INDIVIDUAL-LEVEL DATA } \\
\hline neighbors of different race & 4,587 & 0.12 & 0.32 & 0.00 & 1.00 \\
\hline foreing neighbors & 4,581 & 0.11 & 0.32 & 0.00 & 1.00 \\
\hline interpersonal trust & 4,503 & 0.34 & 0.47 & 0.00 & 1.00 \\
\hline civic cooperation & 4,628 & 23.89 & 4.30 & 0.00 & 27.00 \\
\hline fight against crime & 1,367 & 0.30 & 0.45 & 0 & 1 \\
\hline immigrants increase crime & 867 & 0.53 & 0.50 & 0 & 1 \\
\hline
\end{tabular}


Table 2: Migrants and local security spending. Results from fixed effects models.

\begin{tabular}{lcccccc}
\hline Dep.var.: Security spending & (i) & (ii) & (iii) & (iv) & (v) & (vi) \\
\cline { 2 - 7 } & No controls & Controls & $\begin{array}{c}\text { Excluding } \\
\text { prov. } \\
\text { capitals }\end{array}$ & $\begin{array}{c}\text { Excluding } \\
\text { municip. } \\
<15 \mathrm{~K}\end{array}$ & $\begin{array}{c}\text { Excluding } \\
\text { RSS }\end{array}$ & $\begin{array}{c}\text { Excluding } \\
\text { top 5 } \\
\text { senders }\end{array}$ \\
\cline { 2 - 7 } & & & & & & \\
& & & & & & $0.06^{*}$ \\
Migrants (\%) & $0.03^{* * *}$ & $0.03^{* * *}$ & $0.02^{* *}$ & $0.02^{* *}$ & $0.03^{* *}$ \\
& $(0.01)$ & $(0.01)$ & $(0.01)$ & $(0.03)$ & $(0.01)$ & $(0.01)$ \\
\hline Years & $2003-15$ & $2003-15$ & $2003-15$ & $2003-15$ & $2003-15$ & $2003-15$ \\
Municipalities & 7243 & 7243 & 7137 & 623 & 6196 & 7243 \\
Observations & 94159 & 94159 & 92781 & 8099 & 80548 & 94159 \\
\hline
\end{tabular}

All regressions but model 1 include: population density, the share of $65+$, population, average income, domestic stability pact and time dummies. Model 3 excludes municipalities that are administrative centres of the provinces. Model 4 does not include municipalities with population lower than 15000 inhabitants. Model 5 excludes regions with special status (RSS): Sardinia, Sicily, Trentino-Alto Adige, Aosta Valley and Friuli-Venezia Giulia. Model 6 excludes migrants from Romania, Morocco, Albania, China, Ukraine. Standard errors are clustered at the municipality level. ${ }^{* * *}$ significant at $1 \%,{ }^{* *}$ significant at $5 \%{ }^{*}$ significant at $10 \%$. 
Table 3: Migrants and local security spending. Results from 2SLS models.

\begin{tabular}{|c|c|c|c|c|c|c|}
\hline \multirow[t]{2}{*}{ Dep.var.: Security spending } & (i) & (ii) & (iii) & (iv) & (v) & (vi) \\
\hline & No controls & Controls & $\begin{array}{l}\text { Excluding } \\
\text { prov. } \\
\text { capital }\end{array}$ & $\begin{array}{c}\text { Excluding } \\
\text { mun. } \\
<15 \mathrm{~K}\end{array}$ & $\begin{array}{c}\text { Excluding } \\
\text { RSS }\end{array}$ & $\begin{array}{l}\text { Excluding } \\
\text { top } 5 \\
\text { senders }\end{array}$ \\
\hline Migrants (\%) & $\begin{array}{c}0.15^{* * *} \\
(0.05)\end{array}$ & $\begin{array}{l}0.16^{* *} \\
(0.06)\end{array}$ & $\begin{array}{l}0.15^{* *} \\
(0.07)\end{array}$ & $\begin{array}{c}0.30^{* * *} \\
(0.09)\end{array}$ & $\begin{array}{l}0.12^{*} \\
(0.07)\end{array}$ & $\begin{array}{c}0.17 \\
(0.21)\end{array}$ \\
\hline \multicolumn{7}{|l|}{ First-StaGe } \\
\hline$\widehat{\text { Migrants }(\%)}$ & $\begin{array}{c}0.22^{* * *} \\
(0.02)\end{array}$ & $\begin{array}{c}0.18^{* * *} \\
(0.02)\end{array}$ & $\begin{array}{l}0.18^{* *} \\
(0.02)\end{array}$ & $\begin{array}{c}0.44^{* * *} \\
(0.06)\end{array}$ & $\begin{array}{c}0.17^{* * *} \\
(0.02)\end{array}$ & $\begin{array}{c}0.23^{* * *} \\
(0.06)\end{array}$ \\
\hline First-stage F-stat & 112 & 93 & 88 & 56 & 75 & 15 \\
\hline Years & $2003-15$ & 2003-15 & $2003-15$ & $2003-15$ & $2003-15$ & $2003-15$ \\
\hline Municipalities & 7243 & 7243 & 7137 & 623 & 6196 & 7243 \\
\hline Observations & 94159 & 94159 & 92781 & 8099 & 80548 & 94159 \\
\hline
\end{tabular}

All regressions but model 1 include: population density, the share of $65+$, population, average income, domestic stability pact and time dummies. The share of migrants is instrumented with the predicted share of migrants stemming from countries that joined the EU between 2003 and 2015, multiplied by a time dummy that equals one for years since the accession and zero otherwise. Model 3 excludes municipalities that are administrative centers of the provinces. Model 4 does not include municipalities with population lower than 15000 inhabitants. Model 5 excludes regions with special status (RSS): Sardinia, Sicily, Trentino-Alto Adige, Aosta Valley and Friuli-Venezia Giulia. Model 6 excludes migrants from Romania, Morocco, Albania, China, Ukraine. Standard errors are clustered at the municipality level. ${ }^{* *}$ significant at $1 \%,{ }^{* *}$ significant at $5 \%{ }^{*}$ significant at $10 \%$. 
Table 4: Robustness checks: migrants and local security spending. Results from 2SLS models.

\begin{tabular}{|c|c|c|c|}
\hline Dep.var.: Security spending & (i) & (ii) & (iii) \\
\hline Migrants (\%) & $\begin{array}{l}0.16^{* *} \\
(0.07)\end{array}$ & $\begin{array}{l}0.16^{* *} \\
(0.07)\end{array}$ & $\begin{array}{l}0.11^{*} \\
(0.06)\end{array}$ \\
\hline Grantst-1 & $\begin{array}{c}-0.16^{* *} \\
(0.06)\end{array}$ & & \\
\hline Fees \& chargest-1 & & $\begin{array}{c}0.20 \\
(0.19)\end{array}$ & \\
\hline Security spending-i (\%) & & & $\begin{array}{c}0.24^{* * *} \\
(0.02)\end{array}$ \\
\hline \multicolumn{4}{|l|}{ First-STAGE } \\
\hline$\widehat{\text { Migrants }}(\%)$ & $\begin{array}{c}0.16^{* * *} \\
(0.02)\end{array}$ & $\begin{array}{c}0.16^{* * *} \\
(0.02)\end{array}$ & $\begin{array}{c}0.18^{* * *} \\
(0.02)\end{array}$ \\
\hline First-stage F-stat & 78 & 78 & 91 \\
\hline Years & 2004-15 & $2004-15$ & $2003-15$ \\
\hline Municipalities & 7243 & 7243 & 7243 \\
\hline Observations & 86916 & 86916 & 94159 \\
\hline
\end{tabular}


Table 5: Genetic, linguistic and religious distance and local security spending. Results from 2SLS models.

\begin{tabular}{|c|c|c|c|c|}
\hline \multirow[t]{3}{*}{ Dep.var.: Security spending } & (i) & (ii) & (iii) & (iv) \\
\hline & \multicolumn{4}{|c|}{ Distance } \\
\hline & Genetic & $\begin{array}{l}\text { Linguistic } \\
\text { (cognate) }\end{array}$ & $\begin{array}{c}\text { Linguistic } \\
\text { (common nodes) }\end{array}$ & Religious \\
\hline $\mathrm{WCD}_{\text {int }}$ & $\begin{array}{c}0.21^{* * *} \\
(0.08)\end{array}$ & $\begin{array}{c}0.12^{* * *} \\
(0.04)\end{array}$ & $\begin{array}{c}0.06^{* *} \\
(0.02)\end{array}$ & $\begin{array}{l}0.05^{* *} \\
(0.02)\end{array}$ \\
\hline \multicolumn{5}{|l|}{ First-STAGE } \\
\hline$\widehat{\mathrm{WCD}_{\text {int }}}$ & $\begin{array}{c}0.07^{* * *} \\
(0.01)\end{array}$ & $\begin{array}{c}0.16^{* * *} \\
(0.02)\end{array}$ & $\begin{array}{c}0.24^{* * *} \\
(0.02)\end{array}$ & $\begin{array}{c}0.25^{* * *} \\
(0.02)\end{array}$ \\
\hline First-stage F-stat & 39 & 42 & 89 & 96 \\
\hline Years & 2003-15 & 2003-15 & 2003-15 & 2003-15 \\
\hline Municipalities & 7243 & 7243 & 7243 & 7243 \\
\hline Observations & 94159 & 94159 & 94159 & 94159 \\
\hline
\end{tabular}

All regressions include: population density, the share of $65+$, population, average income, domestic stability pact and time dummies. The indicators of cultural distance are instrumented by the predicted weighted cultural distance. Standard errors are clustered at the municipality level. ${ }^{* *}$ significant at $1 \%,{ }^{* *}$ significant at $5 \%{ }^{*}$ significant at $10 \%$. 
Table 6: Migrants and number of police officers. Results from 2SLS models.

\begin{tabular}{|c|c|c|c|c|c|}
\hline \multirow[t]{3}{*}{ Dep.var.: Police officers } & (i) & (ii) & (iii) & (iv) & (v) \\
\hline & & \multicolumn{4}{|c|}{ Distance } \\
\hline & & Genetic & $\begin{array}{c}\text { Linguistic } \\
\text { (cognate) }\end{array}$ & $\begin{array}{l}\text { Linguistic } \\
\text { (common } \\
\text { nodes) }\end{array}$ & Religious \\
\hline Migrants (\%) & $\begin{array}{l}0.21^{* *} \\
(0.05)\end{array}$ & & & & \\
\hline $\mathrm{WCD}_{\text {int }}$ & & $\begin{array}{c}0.30^{* * *} \\
(0.08)\end{array}$ & $\begin{array}{c}0.15^{* * *} \\
(0.04)\end{array}$ & $\begin{array}{c}0.08^{* * *} \\
(0.02)\end{array}$ & $\begin{array}{c}0.07^{* * *} \\
(0.02)\end{array}$ \\
\hline First-stage F-stat & 93 & 40 & 33 & 88 & 104 \\
\hline Years & 2003-15 & 2003-15 & 2003-15 & 2003-15 & $2003-15$ \\
\hline Municipalities & 5218 & 5218 & 5218 & 5218 & 5218 \\
\hline Observations & 67834 & 67834 & 67834 & 67834 & 67834 \\
\hline
\end{tabular}

All regressions include: population density, the share of $65+$, population, average income, domestic stability pact and time dummies. The indicators of cultural distance are instrumented by the predicted weighted cultural distance. Standard errors are clustered at the municipality level. ${ }^{* *}$ significant at $1 \%,{ }^{* *}$ significant at $5 \%{ }^{*}$ significant at $10 \%$. 
Table 7: Transmission mechanism: Do migrants increase crime?

\begin{tabular}{|c|c|c|c|c|c|c|}
\hline \multirow[t]{3}{*}{ Dep.var.: Crime rate } & (i) & (ii) & (iii) & (iv) & (v) & (vi) \\
\hline & & & \multicolumn{4}{|c|}{ Distance } \\
\hline & & & Genetic & $\begin{array}{c}\text { Linguistic } \\
\text { (cognate) }\end{array}$ & $\begin{array}{c}\text { Linguistic } \\
\text { (common } \\
\text { nodes) }\end{array}$ & Religious \\
\hline Migrants (\%) & $\begin{array}{l}-0.00 \\
(0.00)\end{array}$ & $\begin{array}{l}-0.00 \\
(0.00)\end{array}$ & & & & \\
\hline Security spending & & $\begin{array}{l}-0.00 \\
(0.00)\end{array}$ & & & & \\
\hline $\mathrm{WCD}_{\text {int }}$ & & & $\begin{array}{c}0.00 \\
(0.00)\end{array}$ & $\begin{array}{l}-0.00 \\
(0.00)\end{array}$ & $\begin{array}{l}-0.00 \\
(0.00)\end{array}$ & $\begin{array}{l}-0.00 \\
(0.00)\end{array}$ \\
\hline Years & 2003-15 & 2003-15 & 2003-15 & 2003-15 & 2003-15 & 2003-15 \\
\hline Provinces & 93 & 93 & 93 & 93 & 93 & 93 \\
\hline Observations & 1209 & 1209 & 1209 & 1209 & 1209 & 1209 \\
\hline
\end{tabular}

All regression are estimated using province-level data. Controls include: population density, the share of $65+$, population, average income and time dummies. Standard errors are clustered at the province level. ${ }^{* * *}$ significant at $1 \%,{ }^{* *}$ significant at $5 \%{ }^{*}$ significant at $10 \%$. 
Table 8: Transmission mechanism: Fear of crime.

\begin{tabular}{|c|c|c|c|c|}
\hline & \multicolumn{2}{|c|}{ Dep.var.: Fight against crime } & \multicolumn{2}{|c|}{ Dep.var.: Immigrants increase crime } \\
\hline & (i) & (ii) & (iii) & (iv) \\
\hline Neighbors of different race & $\begin{array}{l}0.08^{* *} \\
(0.04)\end{array}$ & & $\begin{array}{c}0.14^{* * *} \\
(0.05)\end{array}$ & \\
\hline Foreign neighbors & & $\begin{array}{c}0.13^{* * *} \\
(0.04)\end{array}$ & & $\begin{array}{c}0.17^{* * *} \\
(0.05)\end{array}$ \\
\hline Years & & & & \\
\hline Observations & 1367 & 1367 & 867 & 867 \\
\hline
\end{tabular}

Marginal effects shown. All regressions control for: gender, marital status, seven dummies for employment status, squares in ages, number of kids, religion, two dummies for income level. Standard errors are robust to heteroskedasticty. ${ }^{* *}$ significant at $1 \%,{ }^{* *}$ significant at $5 \% *$ significant at $10 \%$ 
Table 9: Transmission mechanism: Do migrants erode social and civic capital?

\begin{tabular}{|c|c|c|c|c|c|}
\hline \multirow[t]{4}{*}{ Panel A } & \multicolumn{5}{|c|}{$\begin{array}{c}\text { DEPENDENT VARIABLE } \\
\text { Number of non-profit organizations per capita }\end{array}$} \\
\hline & \multirow[t]{3}{*}{ (i) } & (ii) & (iii) & (iv) & (v) \\
\hline & & \multicolumn{4}{|c|}{ Distance } \\
\hline & & Genetic & $\begin{array}{c}\text { Linguistic } \\
\text { (cognate) }\end{array}$ & $\begin{array}{c}\text { Linguistic } \\
\text { (common } \\
\text { nodes) }\end{array}$ & Religious \\
\hline Migrants (\%) & $\begin{array}{c}-0.04^{*} \\
(0.02)\end{array}$ & & & & \\
\hline $\mathrm{WCD}_{\text {int }}$ & & $\begin{array}{l}-0.01 \\
(0.01)\end{array}$ & $\begin{array}{c}-0.02^{*} \\
(0.01)\end{array}$ & $\begin{array}{c}-0.01^{*} \\
(0.01)\end{array}$ & $\begin{array}{l}-0.01 \\
(0.01)\end{array}$ \\
\hline Years & $2001 ; 2011$ & $2001 ; 2011$ & $2001 ; 2011$ & $2001 ; 2011$ & $2001 ; 2011$ \\
\hline Municipalities & 6975 & 6975 & 6975 & 6975 & 6975 \\
\hline Observations & 13950 & 13950 & 13950 & 13950 & 13950 \\
\hline \multirow[t]{3}{*}{ Panel B } & & \multicolumn{4}{|c|}{ DEPENDENT VARIABLE } \\
\hline & & \multicolumn{2}{|c|}{ Interpersonal trust } & \multicolumn{2}{|c|}{ Civic cooperation } \\
\hline & & (i) & (ii) & (iii) & (iv) \\
\hline Neighbors of different race & & $\begin{array}{c}-0.11^{* * *} \\
(0.02)\end{array}$ & & $\begin{array}{c}-0.81^{* * *} \\
(0.22)\end{array}$ & \\
\hline Foreign neighbors & & & $\begin{array}{l}-0.12^{* * *} \\
\quad(0.02)\end{array}$ & & $\begin{array}{l}-0.95^{* * *} \\
(0.22)\end{array}$ \\
\hline Years & & \multicolumn{4}{|c|}{$1990 ; 1999 ; 2009$} \\
\hline Observations & & 4587 & 4581 & 4635 & 4628 \\
\hline
\end{tabular}




\section{- Online Appendix -}

\section{A.1 Municipal spending and immigration in Italian municipalities}

Italian municipalities are responsible for many of the basic civil functions, such as maintaining a registry of births and deaths. They also provide several pivotal public services including social welfare services, territorial development, local transport, infant school education, sports and cultural facilities, municipal police, and public utilities such as water supply and waste disposal. Municipalities are also responsible for planning of local areas and infrastructure networks. According to our data, municipalities' total expenditure during the period 2003-2015 was, on average, about 80 billions, but it has steadily declined from 2003 to 2012, reaching a minimum in 2012, the year of the sovereign public debt crisis, when the central government has reduced the funds transferred to municipalities (see Figure A.1). Municipalities are the lowest level of government, yet municipal spending makes up a significant portion of total government expenditure, as the ratio of municipal expenditure to general government expenditure ranges between $8 \%$ and $12 \%$

[ Figure A.1 in here]

In terms of current revenues, one-third of the funding comes from the upper levels of the governments, to finance a number of programs carried out on behalf of the central and regional governments. Following a lengthy process of fiscal devolution, municipalities must rely also on their own revenues, which account for $45 \%$ of their total current revenues, to fund local services and facilities. In particular, property taxes and sales and use taxes are the primary funding sources for many services that do not have a dedicated central or regional funding source. The main local tax is the property tax, called IMU (Imposta municipale unica), introduced in 1992 and imposed on "real estates" (land and permanently attached improvements such as buildings). This tax is paid every year by property owners directly to the municipality where the property is located. Another important revenue source is the tax or tariff on urban waste disposal, the Tari (Tassa Rifiuti), and a surtax on personal income (Addizionale comunale Irpef). Additional revenues (25\% of the municipal budget) can be generated through user fees, linked to local provision of various services such as parking permits, occupation of public areas, and use of billboards.

Turning to the issue of immigration, note that since the Italian unification in 1861, Italy was one of the leading European emigration countries. Between 1880 and 1976, about 13 million Italians left the country. Yet, since the second half of the 1970s, when net migration became positive, the country started receiving large migration inflows from Third World countries, and later from Central and Eastern Europe. The number of migrants in percentage of total population between 2003 and 2015 was approximately $6.5 \%$. In terms of country of origin, immigrants stem from 189 nationalities, the largest groups are from Romania (19.5\%), Albania (12\%) and Morocco (11\%), respectively. Interestingly, $92 \%$ of foreign residents belong to non-OECD countries.

\footnotetext{
${ }^{22}$ Municipalities' current expenditure was on average 55 billion euros per year in the same period, approximately $70 \%$ of the municipalities' total expenditure.
} 


\section{A.2 How immigration affects local public finance}

In this section, we examine the impact of migrants on local revenue and spending. We then discuss how the composition of public spending changes according to the share of migrants. We run models based on equation (1), where depending on the model specifications, the dependent variable is i) per capita total revenue, ii) per capita total spending, iii) per capita total deficit spending and iv) the share of public spending on a given item for municipality $i$ at time $t$. Table A.1 shows the effect of immigration on total and disaggregated local public spending. Column (i) presents the relationship between the share of migrants and total municipal revenues and indicates that immigration reduces the per-capita revenue: a one percentage point increase in the share of migrants leads to a decrease of 8.25 euros per-capita in local revenues. This is not surprising, as immigrants are likely to have a relatively lower income than the local population, thus making a smaller fiscal contribution. As a consequence, we also find that an increase in the share of migrants generates a reduction in total local spending (see column (ii)): a one percentage point increase in the share of migrants leads to a decrease in local spending of 5.82 euros per-capita. It is worth noting that the decrease in local spending is smaller than the corresponding decline in local revenues. In other words, the presence of migrants seems to be associated with a decrease in the municipal surplus, i.e., the difference between revenue and spending, as column (iii) shows.

Municipalities are responsible for range of important public services, and to facilitate the empirical analysis, we aggregate them into six groups, according to the type of public good provided (see also Table 1). Reading across the last columns of results in Table A.1. we find that immigration does not only reduce local revenues and the size of municipal expenditures, but it also affects its reallocation. First, the increase in local security spending detected in Table 2 is at the expense of the budget allocated to culture, sport and tourism (CST) as well as economic development (SB), which are negatively affected by an increase in the number of immigrants. In particular, a one percentage point increase in the share of migrants leads to a decrease of 0.02 and 0.04 percentage points in the quota of CST and SB spending categories, respectively. On the contrary, a one percentage point increase in the share of migrants is associated to an increase of 0.05 percentage points in the quota of public spending devoted to social services. These results suggest that the local policymaker, as a response to an increase in the number of immigrants in her territory, mainly adjusts her spending decisions by transferring money from culture, sport, tourism and local economic development to police protection and welfare programs. Perhaps it comes as no surprise that slow-moving categories, that are related to the provision of essential annual public services, such as Administration and Management Services (Admin), Roads, Transport Services, and Planning and Environment (TPE) are not significantly affected by migrants. For the above categories, the incumbent is likely to face more constraints when trying to manipulate them. 


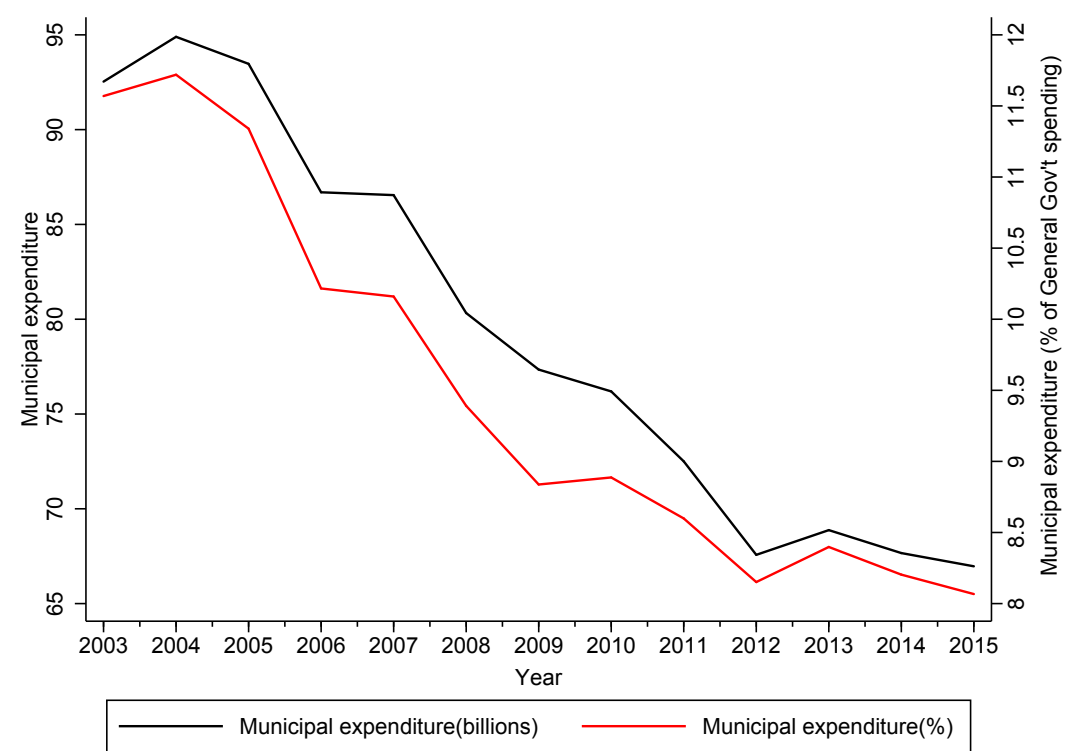

Figure A.1: Municipal Spending (Source: ISTAT) 
Table A.1: Migrants and local public finance. Results from fixed effects models.

\begin{tabular}{|c|c|c|c|c|c|c|c|c|}
\hline \multirow[b]{2}{*}{ Dep. var. } & \multicolumn{3}{|c|}{ total } & \multicolumn{5}{|c|}{ disaggregated by expenditure functions } \\
\hline & revenue & spending & surplus & Admin & TPE & CST & $\mathrm{SE}$ & SB \\
\hline Migrants (\%) & $\begin{array}{c}-8.25^{* * *} \\
(1.74)\end{array}$ & $\begin{array}{c}-5.82^{* * *} \\
(1.29)\end{array}$ & $\begin{array}{c}-2.42^{* *} \\
(0.96)\end{array}$ & $\begin{array}{l}-0.03 \\
(0.03)\end{array}$ & $\begin{array}{c}0.02 \\
(0.03)\end{array}$ & $\begin{array}{c}-0.02^{* * *} \\
(0.01)\end{array}$ & $\begin{array}{c}0.05^{* *} \\
(0.02)\end{array}$ & $\begin{array}{c}-0.04^{* * *} \\
(0.01)\end{array}$ \\
\hline Years & 2003-15 & 2003-15 & 2003-15 & 2003-15 & 2003-15 & 2003-15 & 2003-15 & 2003-15 \\
\hline Municipalities & 7243 & 7243 & 7243 & 7243 & 7243 & 7243 & 7243 & 7243 \\
\hline Observations & 94159 & 94159 & 94159 & 94159 & 94159 & 94159 & 94159 & 94159 \\
\hline
\end{tabular}

Admin: Administration \& Management Services. TPE: Roads \& Transport Services, Planning \& Environment Services. CST: Culture, Sport and Tourism Services. SE: Social Services and Education Services. SB: Economic development. All regressions include: population density, the share of $65+$, population, average income, domestic stability pact and time dummies. Standard errors are clustered at the municipality level. ${ }^{* *}$ significant at $1 \%,{ }^{* *}$ significant at $5 \%{ }^{*}$ significant at $10 \%$. 
Table A.2: Correlation between economic indicators and predicted share of migrants.

\begin{tabular}{|c|c|c|c|c|c|c|c|c|c|c|c|c|}
\hline Dep.var.: Migrants (\%) & 2004 & 2005 & 2006 & 2007 & 2008 & 2009 & 2010 & 2011 & 2012 & 2013 & 2014 & 2015 \\
\hline Population $_{2001-1991}$ & $\begin{array}{l}-0.00 \\
(0.00)\end{array}$ & $\begin{array}{l}-0.00 \\
(0.00)\end{array}$ & $\begin{array}{l}-0.00 \\
(0.00)\end{array}$ & $\begin{array}{l}-0.00 \\
(0.00)\end{array}$ & $\begin{array}{l}-0.00 \\
(0.00)\end{array}$ & $\begin{array}{l}-0.00 \\
(0.00)\end{array}$ & $\begin{array}{l}-0.00 \\
(0.00)\end{array}$ & $\begin{array}{l}-0.00 \\
(0.00)\end{array}$ & $\begin{array}{l}-0.00 \\
(0.00)\end{array}$ & $\begin{array}{l}-0.00 \\
(0.00)\end{array}$ & $\begin{array}{l}-0.00 \\
(0.00)\end{array}$ & $\begin{array}{l}-0.00 \\
(0.00)\end{array}$ \\
\hline Observations & 7232 & 7232 & 7232 & 7232 & 7232 & 7232 & 7232 & 7232 & 7232 & 7232 & 7232 & 7232 \\
\hline Population density $_{200}$ & $\begin{array}{l}-0.00 \\
(0.00)\end{array}$ & $\begin{array}{l}-0.00 \\
(0.00)\end{array}$ & $\begin{array}{l}-0.00 \\
(0.00)\end{array}$ & $\begin{array}{l}-0.00 \\
(0.00)\end{array}$ & $\begin{array}{l}-0.00 \\
(0.00)\end{array}$ & $\begin{array}{l}-0.00 \\
(0.00)\end{array}$ & $\begin{array}{l}-0.00 \\
(0.00)\end{array}$ & $\begin{array}{l}-0.00 \\
(0.00)\end{array}$ & $\begin{array}{l}-0.00 \\
(0.00)\end{array}$ & $\begin{array}{l}-0.00 \\
(0.00)\end{array}$ & $\begin{array}{l}-0.00^{*} \\
(0.00)\end{array}$ & $\begin{array}{l}-0.00^{*} \\
(0.00)\end{array}$ \\
\hline Observations & 7232 & 7232 & 7232 & 7232 & 7232 & 7232 & 7232 & 7232 & 7232 & 7232 & 7232 & 7232 \\
\hline Income p.c. $2002-2001$ & $\begin{array}{l}0.00 \\
(0.00)\end{array}$ & $\begin{array}{l}0.00 \\
(0.00)\end{array}$ & $\begin{array}{l}0.00 \\
(0.00)\end{array}$ & $\begin{array}{l}0.00 \\
(0.00)\end{array}$ & $\begin{array}{l}0.00 \\
(0.00)\end{array}$ & $\begin{array}{l}0.00 \\
(0.00)\end{array}$ & $\begin{array}{l}0.00 \\
(0.00)\end{array}$ & $\begin{array}{l}0.00 \\
(0.00)\end{array}$ & $\begin{array}{l}0.00 \\
(0.00)\end{array}$ & $\begin{array}{l}0.00 \\
(0.00)\end{array}$ & $\begin{array}{l}0.00 \\
(0.00)\end{array}$ & $\begin{array}{l}0.00 \\
(0.00)\end{array}$ \\
\hline Observations & 7205 & 7205 & 7205 & 7205 & 7205 & 7205 & 7205 & 7205 & 7205 & 7205 & 7205 & 7205 \\
\hline Houses 2001-1991 & $\begin{array}{l}0.04 \\
(0.10)\end{array}$ & $\begin{array}{l}0.05 \\
(0.11)\end{array}$ & $\begin{array}{l}0.06 \\
(0.13)\end{array}$ & $\begin{array}{l}-0.40 \\
(0.38)\end{array}$ & $\begin{array}{l}-0.43 \\
(0.43)\end{array}$ & $\begin{array}{l}-0.43 \\
(0.43)\end{array}$ & $\begin{array}{l}-0.41 \\
(0.45)\end{array}$ & $\begin{array}{l}-0.34 \\
(0.36)\end{array}$ & $\begin{array}{l}-0.35 \\
(0.40)\end{array}$ & $\begin{array}{l}-0.38 \\
(0.46)\end{array}$ & $\begin{array}{l}-0.36 \\
(0.47)\end{array}$ & $\begin{array}{l}-0.38 \\
(0.49)\end{array}$ \\
\hline Observations & 7232 & 7232 & 7232 & 7232 & 7232 & 7232 & 7232 & 7232 & 7232 & 7232 & 7232 & 7232 \\
\hline Unenmployment rate $2001-1991$ & $\begin{array}{l}-0.00 \\
(0.00)\end{array}$ & $\begin{array}{l}-0.00 \\
(0.00)\end{array}$ & $\begin{array}{r}-0.00 \\
(0.00)\end{array}$ & $\begin{array}{l}-0.00 \\
(0.00)\end{array}$ & $\begin{array}{l}-0.00 \\
(0.00)\end{array}$ & $\begin{array}{l}-0.00 \\
(0.00)\end{array}$ & $\begin{array}{l}-0.00 \\
(0.00)\end{array}$ & $\begin{array}{l}-0.00 \\
(0.00)\end{array}$ & $\begin{array}{l}-0.00 \\
(0.00)\end{array}$ & $\begin{array}{l}-0.00 \\
(0.00)\end{array}$ & $\begin{array}{l}-0.00 \\
(0.00)\end{array}$ & $\begin{array}{l}-0.00 \\
(0.00)\end{array}$ \\
\hline Observations & 7232 & 7232 & 7232 & 7232 & 7232 & 7232 & 7232 & 7232 & 7232 & 7232 & 7232 & 7232 \\
\hline
\end{tabular}

Standard errors are clustered at the municipality level. ${ }^{* *}$ significant at $1 \%,{ }^{* *}$ significant at $5 \%{ }^{*}$ significant at $10 \%$. 
Table A.3: Replication of the main results using province-level data.

\begin{tabular}{|c|c|c|c|c|}
\hline \multirow[t]{2}{*}{ Dep.var.: Security spending } & (i) & (ii) & (iii) & (iv) \\
\hline & OLS & 2SLS & 2SLS & 2SLS \\
\hline Migrants (\%) & $\begin{array}{c}0.21^{* * *} \\
(0.04)\end{array}$ & $\begin{array}{c}0.40^{* * *} \\
(0.25)\end{array}$ & $\begin{array}{l}0.35 \\
(0.14)\end{array}$ & \\
\hline Migrants $2015-2003(\%)$ & & & & $\begin{array}{c}0.42^{* *} \\
(0.20)\end{array}$ \\
\hline \multicolumn{5}{|l|}{ First-STAGE } \\
\hline Migrants (\%) & & $\begin{array}{c}0.42^{* * *} \\
(0.06)\end{array}$ & $\begin{array}{c}0.05 \\
(0.03)\end{array}$ & \\
\hline Migrants $_{2015-2003}(\%)$ & & & & $\begin{array}{c}-0.27^{* * *} \\
(0.07)\end{array}$ \\
\hline First-stage F-stat & & 46 & 3 & 15 \\
\hline Instrument & & $\begin{array}{l}2003 \text { migrants } \\
\text { distribution }\end{array}$ & $\begin{array}{l}1936 \text { migrants } \\
\text { distribution }\end{array}$ & $\begin{array}{l}1929 \text { vote-share } \\
\text { pro-fascism party }\end{array}$ \\
\hline Years & $2003-15$ & $2003-15$ & $2003-15$ & $2003 / 15$ \\
\hline Provinces & 103 & 103 & 89 & 88 \\
\hline Observations & 1339 & 1339 & 1157 & 88 \\
\hline
\end{tabular}

All regressions but model 4 include: population density, the share of $65+$, population, average income, domestic stability pact and time dummies. The share of migrants in model 2 is instrumented with the predicted share of migrants stemming from countries that joined the EU between 2003 and 2015, multiplied by a time dummy that equals one for years since the accession and zero otherwise. The share of migrants in model 3 is instrumented with the predicted share of migrants from 1936 stemming from countries that joined the EU between 2003 and 2015, multiplied by a time dummy that equals one for years since the accession and zero otherwise. The $2003-2015$ change in the share of migrants in Model 4 is is instrumented with the share of vote pro-fascism at the provincial level in the national election of 1929. The 2003-2015 changes in following variables are used as controls: population density, the share of aged, population, average income. Standard errors are clustered at the provincial level. ${ }^{* *}$ significant at $1 \%,{ }^{* *}$ significant at $5 \%{ }^{*}$ significant at $10 \%$. 
Table A.4: Robustness check (b). Migrants and local security spending.

\begin{tabular}{|c|c|c|c|c|c|c|}
\hline \multirow[t]{2}{*}{ Dep.var.: Security spending } & (i) & (ii) & (iii) & (iv) & (v) & (vi) \\
\hline & No controls & Controls & $\begin{array}{l}\text { Excluding } \\
\text { prov. } \\
\text { capitals }\end{array}$ & $\begin{array}{c}\text { Excluding } \\
\text { municip. } \\
<15 \mathrm{~K}\end{array}$ & $\begin{array}{l}\text { Excluding } \\
\text { RSS }\end{array}$ & $\begin{array}{c}\text { Excluding } \\
\text { top } 5 \\
\text { senders }\end{array}$ \\
\hline Migrants (\%) & $\begin{array}{c}0.35^{* * *} \\
(0.06)\end{array}$ & $\begin{array}{c}0.38^{* * *} \\
(0.07)\end{array}$ & $\begin{array}{c}0.39^{* * *} \\
(0.07)\end{array}$ & $\begin{array}{c}0.21^{* * *} \\
(0.06)\end{array}$ & $\begin{array}{c}0.36^{* * *} \\
(0.09)\end{array}$ & $\begin{array}{l}1.50 \\
(0.11)\end{array}$ \\
\hline \multicolumn{7}{|l|}{ First-Stage } \\
\hline Migrants (\%) & $\begin{array}{c}0.23^{* * *} \\
(0.02)\end{array}$ & $\begin{array}{c}0.20^{* * *} \\
(0.02)\end{array}$ & $\begin{array}{c}0.19^{* * *} \\
(0.02)\end{array}$ & $\begin{array}{c}0.66^{* * *} \\
(0.05)\end{array}$ & $\begin{array}{c}0.17^{* * *} \\
(0.02)\end{array}$ & $\begin{array}{c}0.07^{* * *} \\
(0.02)\end{array}$ \\
\hline First-stage F-stat & 94 & 81 & 77 & 195 & 53 & 15 \\
\hline Years & $2003-15$ & $2003-15$ & $2003-15$ & $2003-15$ & $2003-15$ & $2003-15$ \\
\hline Municipalities & 7243 & 7243 & 7137 & 623 & 6196 & 7243 \\
\hline Observations & 94159 & 94159 & 92781 & 8099 & 80548 & 94159 \\
\hline
\end{tabular}

All regressions include: population density, the share of $65+$, population, average income, domestic stability pact and time dummies. The share of migrants is instrumented with the predicted share of immigrants from all world countries. Model 3 excludes municipalities The share of migrants is instrumented with the predicted share of immigrants from all world countries. Model 3 excludes municipalities
that are the administrative centres of the provinces. Model 4 excludes municipalities with population lower than 15000 inhabitants. that are the administrative centres of the provinces. Model 4 excludes municipalities with population lower than 15000 inhabitants. 6 excludes immigrants from Romania, Morocco, Albania, China, Ukraine. Standard errors are clustered at the municipality level. ${ }^{* * *}$ significant at $1 \%,{ }^{* *}$ significant at $5 \%{ }^{*}$ significant at $10 \%$. 
Table A.5: Robustness check (a). Migrants and local security spending.

\begin{tabular}{|c|c|c|c|c|c|c|}
\hline \multirow[t]{2}{*}{ Dep.var.: Security spending } & (i) & (ii) & (iii) & (iv) & (v) & (vi) \\
\hline & No controls & Controls & $\begin{array}{l}\text { Excluding } \\
\text { prov. } \\
\text { capitals }\end{array}$ & $\begin{array}{c}\text { Excluding } \\
\text { municip. } \\
<15 \mathrm{~K}\end{array}$ & $\begin{array}{c}\text { Excluding } \\
\text { RSS }\end{array}$ & $\begin{array}{c}\text { Excluding } \\
\text { top } 5 \\
\text { senders }\end{array}$ \\
\hline Migrants (\%) & $\begin{array}{c}0.16^{* * *} \\
(0.06)\end{array}$ & $\begin{array}{c}0.17^{* *} \\
(0.07)\end{array}$ & $\begin{array}{c}0.17^{* *} \\
(0.08)\end{array}$ & $\begin{array}{c}0.31^{* * *} \\
(0.09)\end{array}$ & $\begin{array}{c}0.14 \\
(0.08)\end{array}$ & $\begin{array}{c}0.17 \\
(0.26)\end{array}$ \\
\hline \multicolumn{7}{|l|}{ First-STAGE } \\
\hline Migrants (\%) & $\begin{array}{c}0.38^{* * *} \\
(0.05)\end{array}$ & $\begin{array}{c}0.33^{* * *} \\
(0.05)\end{array}$ & $\begin{array}{c}0.31^{* * *} \\
(0.05)\end{array}$ & $\begin{array}{c}0.92^{* * *} \\
(0.12)\end{array}$ & $\begin{array}{c}0.31^{* * *} \\
(0.05)\end{array}$ & $\begin{array}{c}0.37^{* *} \\
(0.13)\end{array}$ \\
\hline First-stage F-stat & 58 & 51 & 48 & 53 & 40 & 9 \\
\hline Years & 2003-15 & 2003-15 & 2003-15 & 2003-15 & $2003-15$ & $2003-15$ \\
\hline Municipalities & 7243 & 7243 & 7137 & 623 & 6196 & 7243 \\
\hline Observations & 94159 & 94159 & 92781 & 8099 & 80548 & 94159 \\
\hline
\end{tabular}

All regressions but model 1 include: population density, the share of $65+$, population, average income, domestic stability pact and time dummies. The share of migrants is instrumented with the predicted share of immigrants stemming from countries that joined the time dummies. The share of migrants is instrumented with the predicted share of immigrants stemming from countries that joined the EU between 2003 and 2015. Model 3 excludes municipalities that are the administrative centres of the provinces. Model 4 excludes
municipalities with population lower than 15000 inhabitants. Model 5 excludes regions with special status (RSS): Sardinia, Sicily, Trentino-Alto Adige, Aosta Valley and Friuli-Venezia Giulia. Model 6 excludes immigrants from Romania, Morocco, Albania, China, Ukraine. Standard errors are clustered at the municipality level. ${ }^{* *}$ significant at $1 \%,{ }^{* *}$ significant at $5 \%{ }^{*}$ significant at $10 \%$. 
Table A.6: Do migrants increase voting for right-wing parties?

\begin{tabular}{|c|c|c|c|c|c|}
\hline \multirow[t]{3}{*}{ Dep.var.: right-wing mayor } & (i) & (ii) & (iii) & (iv) & (v) \\
\hline & & \multicolumn{4}{|c|}{ Distance } \\
\hline & & Genetic & $\begin{array}{c}\text { Linguistic } \\
\text { (cognate) }\end{array}$ & $\begin{array}{c}\text { Linguistic } \\
\text { (common } \\
\text { nodes) }\end{array}$ & Religious \\
\hline Migrants $_{\mathrm{t}-1}(\%)$ & $\begin{array}{c}0.03^{* *} \\
(0.01)\end{array}$ & & & & \\
\hline $\mathrm{WCD}_{\text {in }, \mathrm{t}-1}$ & & $\begin{array}{c}0.01^{* *} \\
(0.01)\end{array}$ & $\begin{array}{c}0.01 \\
(0.01)\end{array}$ & $\begin{array}{c}0.01^{* *} \\
(0.00)\end{array}$ & $\begin{array}{c}0.01^{* *} \\
(0.00)\end{array}$ \\
\hline Years 2004-15 & 2004-15 & $2004-15$ & 2004-15 & 2004-15 & 2004-15 \\
\hline Municipalities 315 & 315 & 315 & 315 & 315 & 315 \\
\hline Observations 3780 & 3780 & 3780 & 3780 & 3780 & 3780 \\
\hline
\end{tabular}

All regressions include: population density, the share of $65+$, population, average income and time dummies. Standard errors are clustered at the municipality level. ${ }^{* * *}$ significant at $1 \%,{ }^{* *}$ significant at $5 \%{ }^{*}$ significant at $10 \%$. 